\title{
Integrating Forest Management Across the Landscape: A Three Pillar Framework
}

\author{
Edward A. Morgan ${ }^{\mathrm{a}, \mathrm{b} *}$, Tim Cadman ${ }^{\mathrm{a}, \mathrm{c}}$, Brendan Mackey ${ }^{\mathrm{a}}$ \\ ${ }^{a}$ Griffith Climate Change Response Program, Griffith University, Gold Coast Campus, Parklands Drive, \\ Southport, Queensland 4222, Australia; ed.morgan@griffith.edu.au \\ ${ }^{\mathrm{b}}$ Cities Research Institute, Griffith University, Nathan Campus, 170 Kessels Road, Nathan, Queensland 4111, \\ Australia \\ c Institute for Ethics, Governance and Law, Griffith University, Nathan Campus, 170 Kessels Road, Nathan, \\ Queensland 4111, Australia
}

\section{Keywords}

Forest management; Landscape planning; Governance; Ecosystem integrity; Ecosystem services

\begin{abstract}
Forests are vital ecosystems on a global, regional and local scale, but are under threat from a variety of competing land uses. Integrated landscape approaches have been proposed as a way to create sustainable land use for forests and forest communities through a more integrated, holistic approach to governing resources. A variety of principles for managing landscapes have been proposed as a framework for implementation, but these landscape approaches suffer from a limited theoretical and conceptual basis. This paper seeks to address such shortcomings by identifying and integrating the theoretical components of landscape approaches into a common framework. The paper analyses landscape disciplines, practices and activities and the implementation of common landscape-level principles in the context of forest landscapes to identify the underlying key components. The paper argues that management across a forest landscape must be underpinned by three pillars: ecosystem integrity, strong governance systems and effective planning processes.
\end{abstract}

\section{Introduction}

Forests are important ecosystems locally, regionally and globally (Mackey et al. 2015; Millennium Ecosystem Assessment Board 2005; Mori, Lertzman, and Gustafsson 2017). In many places, they are home to communities that have managed their forests for millennia. However, governments and communities are under pressure to allow forests to be cleared or degraded for other land uses for commercial development, including logging, mining, agriculture, and plantations (Kim, Sexton, and Townshend 2015; Leblois, Damette, and Wolfersberger 2017; Bebbington et al. 2018; Notess et al. 2018; Curtis et al. 2018). Over a quarter $(27 \%)$ of global forest loss is attributed to deforestation through permanent land use change for commodity production, with forest degradation due to forestry (26\%) and shifting agriculture (24\%), especially in tropical forest areas (Curtis et al. 2018). Protecting the world's remaining natural forests - i.e. naturally regenerated forest of native species, including primary forest where are there no clearly visible indications of human activities and ecological processes are not significantly disturbed (FAO 2015) - has been identified as critical to addressing both the climate change and biodiversity crises (Mackey et al. 2015; J. E. M. Watson 
et al. 2018; Secretariat of the Convention on Biological Diversity 2014). Increased understanding of the role of natural forests, and especially primary forests, in sequestering and storing atmospheric carbon, thereby helping to mitigate greenhouse gas emissions, and also in providing ecosystem-based adaptation services has added impetus to reducing deforestation and degradation (J. E. M. Watson et al. 2018; Martin and Watson 2016; Dellasala et al. 2020; Mackey et al. 2020).

The world's tropical primary forests are largely situated in developing countries and are often home to Indigenous peoples and local communities who rely on the forests for fuel, food and fibre and have strong cultural attachments to the forest (Jupiter 2017; Schwartzman and Zimmerman 2005; Notess et al. 2018). These communities are facing development pressures resulting in forest loss and degradation and are under pressure to sell or lease their land and forest resources for commercial use or face illegal exploitation of the forest (Zimmerman et al. 2020; Notess et al. 2018; Filer 2012; Nelson et al. 2014; Bebbington et al. 2018), resulting in tensions between development and forest protection.

Attempts to promote sustainable development and reconcile competing uses for forested lands have conventionally been sector-based through actions aimed at implementing alternative forest management strategies that are more environmentally benign (Puettmann et al. 2015), reducing the impact of mining (Dubiński 2013), promoting biodiversity conservation (Franklin 1993; Mori, Lertzman, and Gustafsson 2017), and improving agricultural productivity, thereby reducing the pressure on these ecosystems (Laurance, Sayer, and Cassman 2014). To address these multiple and competing pressures, which often lie outside a conventional forest sectoral approach, integrated approaches to forest management focused at the landscape-level have been proposed.

Integrated landscape approaches have been developed in, and applied to, a range of landscapes, including forest landscapes, and potentially offer a more holistic strategy for sustainable development that accommodates the various interests of diverse stakeholders (Arts et al. 2017; Reed et al. 2016; Sayer et al. 2013). However, recent reviews of integrated landscape approaches have questioned the claimed benefits and effectiveness (Reed et al. 2017; Sayer et al. 2017) and noted the lack of theoretical frameworks (Erbaugh and Agrawal 2017; Reed et al. 2017). Critics point to a lack of an accepted definition of what constitutes a landscape approach, and explanation as to how it differs from other attempts at improving land management. As Erbaugh and Agrawal $(2017,2)$ notes "For the LA [landscape approach] to realize its potential for restoration and sustainable development, it is critically important to develop stronger frameworks and use them to evaluate theories and test models through careful scholarship".

This theoretical paper proposes a framework for understanding and implementing forest management across a landscape. The framework has been developed by synthesising current integrated landscape approaches relevant to tropical primary forest landscapes and developing landscape-level management principles from these. The resulting framework is a theory for integrated landscape approaches using three 'pillars' relevant to tropical forest contexts at the 
landscape-level. This has the potential to support the development of consistent guidance and evaluation to support effective and sustainable forest-based outcomes.

\section{Background}

\subsection{Forests and Forest Landscapes}

Forests, and especially tropical primary forests, provide a wide range of ecosystem services at a local, national, regional and global scale (Perera et al. 2018). The concept of ecosystem services links ecosystem structures and functions to the benefits that accrue from them, with a focus on the benefits to people (de Groot, Wilson, and Boumans 2002; Ehrlich and Mooney 1983). The concept provides a useful boundary concept to link ecological structure and function to human management and use of natural resources (de Groot et al. 2010; Shackleton et al. 2017; Sitas et al. 2014).

Of the world's 4.06 billion hectares of forest, there remains at least 1.11 billion ha of primary forest - those not subject to management for commodity production (Puettmann et al. 2015) and other industrial scale commercial uses and whose structure and function are dominated by natural processes (FAO and UNEP 2020; FAO 2015). They provide ecosystem services with benefits to people at global, national and local levels. At the global scale, it is widely accepted that forests have a key role to play in combatting climate change (IPCC 2015) by providing carbon regulation services. They also have irreplaceable value for terrestrial biodiversity, with forests providing habitats for $80 \%$ of amphibian species, $75 \%$ of bird species and $68 \%$ of mammal species. About $60 \%$ of all vascular plants are found in tropical forests (FAO and UNEP 2020, 20; Barlow et al. 2007; Dirzo and Raven 2003). Primary forests also store globally significant ecosystem carbon stocks and avoiding the emissions that arise from their loss and degradation is critical if climate change targets are to be met (Mackey et al. 2015; Mackey et al. 2020).

Primary forests also provide ecosystem service benefits at regional scales, including the regulation of water quantity and quality, enhanced rainfall, and regional cooling effects (Millennium Ecosystem Assessment Board 2005; Mori, Lertzman, and Gustafsson 2017; Perera et al. 2018; Spracklen, Arnold, and Taylor 2012). At a local scale, communities benefit from multiple forest ecosystem services, including subsistence food supplies, serving as the foundation of Indigenous cultures and associated beliefs and practices, plant fibre for clothing and construction, small-scale timber production for local construction, and firewood for cooking (Mackey et al. 2017; Buckwell et al. 2020; de Groot et al. 2010).

The quality and quantity of forest ecosystem services are related to the ecosystem integrity of a forest, with primary forests providing the highest quantum and quality of provisioning, regulating, cultural and supporting ecosystem service benefits to people, compared to secondary forests, forest managed for commodity production and degraded forests (Moomaw, Masino, and Faison 2019; Nadrowski, Wirth, and Scherer-Lorenzen 2010; Mackey et al. 2015; Moreno-Mateos et al. 2017; Mackey et al. 2020; Mace, Norris, and Fitter 2012). However, the extent to which these differences in ecosystem service provision are recognized hinges on the definition of forest used and the extent to which primary forests can be distinguished from 
planted forests, forests damaged by logging, second-growth forests, and regrowing forest patches within agricultural landscapes (Chazdon et al. 2016).

International standards for forest definitions were originally developed with the aim of assessing and reporting on the status of forest as a growing stock for timber and forest products at global and national scales and are based on minimum thresholds patch size (e.g. 0.5 ha), tree size (e.g. $5 \mathrm{~cm}$ diameter at breast height or $5 \mathrm{~m}$ height) and canopy cover (e.g. $>10 \%$ (FAO 2015; UNFCCC 2001). However, following a definition of landscapes as socio-ecological systems influenced by distinct ecological, historical, political, economic and cultural processes and activities (Dernier et al. 2015), managing forests at the landscape level requires they not be defined as isolated entities, but as integral components of dynamic, multi-functional landscapes, often balancing multiple ecosystems types and actors who use and benefit from them (Chazdon et al. 2016).

Approaches to managing natural forest and tensions between competing land uses is more usefully focused at a landscape level, where in addition to spatial heterogeneity arising from biophysical factors associated with topography, substrate, hydrology and vegetation, the influence of current and historic human influences are also evident (Dernier et al. 2015); in comparison, the minimalist forest definition noted above focuses at a "stand" or "plot" level. From this landscape perspective, primary forests occur in a range of contexts from extensive intact forest landscapes through to scattered remnant patches in agricultural land (Figure 1). A forest landscape, therefore, can be entirely composed of primary forest or contain a mix of primary forest, secondary forest, plantation forest and degraded forest, along with other land covers such as cropping, ranching and human settlements. The forests present in the landscape will provide ecosystem services benefits (Perera et al. 2018) depending on their extent and ecosystem integrity.

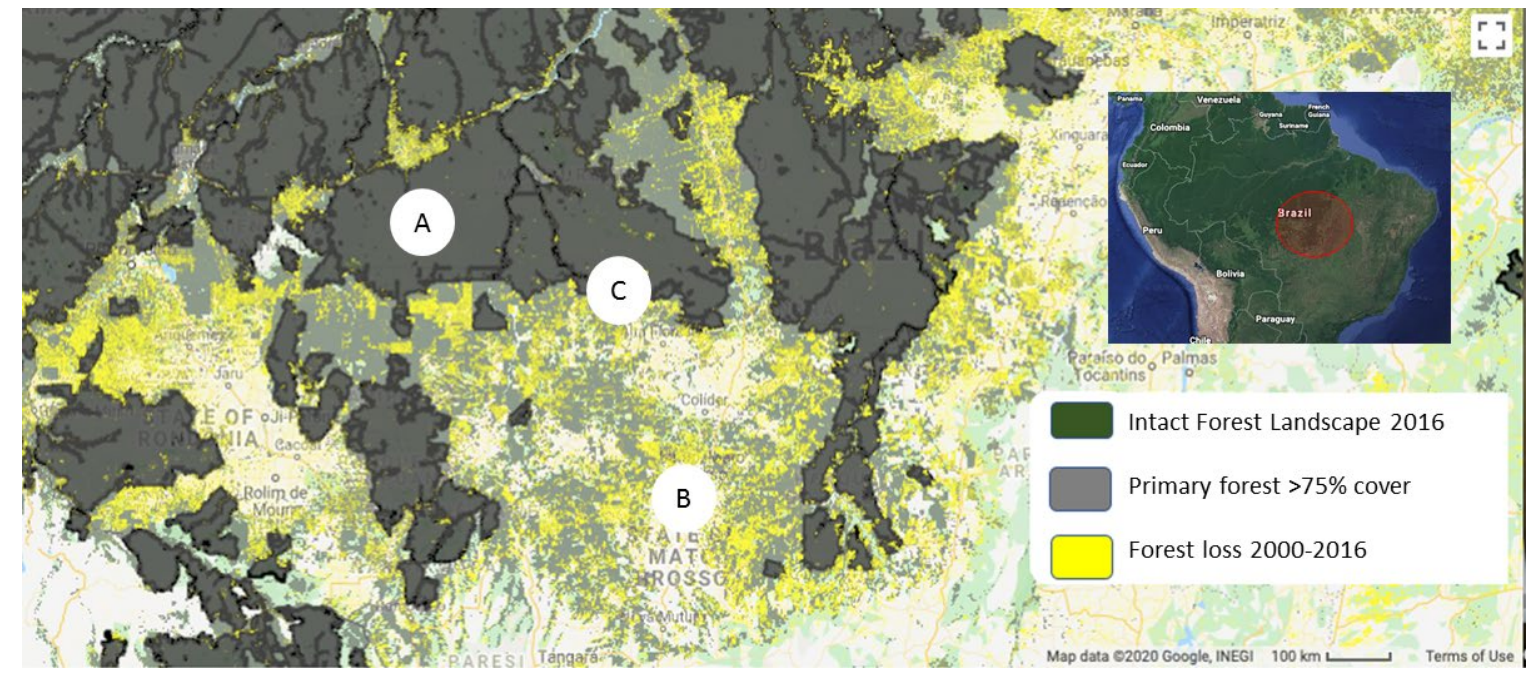

Figure 1. Primary forests and the pressures and opportunities for their conservation, occur in a variety of landscape contexts. From the perspective of forest conservation, three key contexts are illustrated here for south east Brazilian Amazon: (A) Intact Forest Landscapes (landscapes $>50000 \mathrm{ha}^{-1}$ dominated by primary forest) where the challenge is determining land use activities consistent with maintaining the current level of ecosystem integrity; (B) multiple use landscapes with fragmented primary forest patches (defined here as natural tropical forest with canopy cover $>75 \%$ irrespective of forest block size), areas of commercial plantations, industrial-scale 
cropping, and ongoing deforestation - the challenge here is how to implement more sustainable forest landscape planning and management; and $(\mathrm{C})$ the boundary zone where intact forests are a dominant landscape element and land use conflicts are highly evident. Date sources: (Potapov et al. 2017; Hansen et al. 2013).

Forest landscapes are home to communities, often Indigenous communities, that use and manage, and sometimes own the entire forest or if the forest only occurs as remnant patches, the surrounding lands within the landscape (Jupiter 2017; Samndong et al. 2018; Schwartzman and Zimmerman 2005; Filer 2012). Often, the forests are of social and cultural importance to these communities, providing cultural services in addition to the provisioning services of fuel, food and fibre. Cultural practices and social norms have developed that support forest management and protection and maintain the forest landscapes (Phillips 1998; Jupiter 2017). Recent research has highlighted how these communities can be more effective at managing and maintaining these forest landscapes than conventional 'conservation' approaches (Ellis and Porter-Bolland 2008), echoing long-standing calls for community-based forest management (Agrawal, Chhatre, and Hardin 2008; Maraseni et al. 2014; Tavares et al. 2014; Berkes 2010). Considerations of equity and justice in pursuing sustainable development goals mean that these communities must be allowed to determine their preferred development pathways.

However, landscapes and their ecosystem services are affected by interactions at multiple scales (Martín-López et al. 2019). Deforestation and degradation continue globally (Achard et al. 2014; Kim, Sexton, and Townshend 2015; Curtis et al. 2018) due to land use change driven both by both local and global factors (Laurance, Sayer, and Cassman 2014; Leblois, Damette, and Wolfersberger 2017). In some forest landscapes, population increase and development opportunities encourage communities to utilise more and more of the forest to increase agricultural production (Samndong et al. 2018). In other areas, land use change comes from industrial exploitation of the mining, logging, and agricultural potential of these landscapes and the value of resulting products on international markets (Farran 2016; Katovai, Edwards, and Laurance 2015; Megevand et al. 2013; Nelson et al. 2014; Tyukavina et al. 2017; Bebbington et al. 2018). In many areas, these factors combine to place primary forests under extreme threat, and these rapidly changing land uses have significant impacts for the surrounding landscape that depends upon it. Hence, avoiding forest loss and degradation requires reconciling competing interests across land uses and sectors. For example, crop production can be increased by expanding agricultural land at the expense of natural forest cover. However, cross-sectoral management at the landscape level could identify opportunities for boosting agricultural productivity within existing agricultural land.

\subsection{Integrated Landscape Approaches to Forest Management}

Integrated landscape approaches aim to take a more holistic and cross-sectoral approach than conventional land management approaches, including forest management (Arts et al. 2017; Reed et al. 2016; Sayer et al. 2013). They are presented as a challenge to conventional siloed approaches that might focus on a single sector (e.g. agriculture or conservation), land use (e.g. forests) or element (e.g. environmental, social or economic) of the landscape (McCall 2016; Sayer et al. 2013; Freeman, Duguma, and Minang 2015). Integrated landscape approaches also aim for more than managing at a landscape scale or managing sectors within a landscape, 
instead seeking to integrate the multiple ecological, economic and development, sociocultural and political aspects of the multiple land uses and sectors of a landscape (Arts et al. 2017; Freeman, Duguma, and Minang 2015). Hence, they hold significant potential for tropical primary forest landscapes, and are being applied in a range of forest landscapes (Sayer, Maginnis, and Laurie 2005; Nielsen 2016; Ianni and Geneletti 2010; Angelstam et al. 2019).

Although there is significant agreement on the benefits of integrated landscape approaches, recent reviews have highlighted the lack of empirical evidence for these hoped for benefits and the challenges faced in implementing them (Reed et al. 2017; Sayer et al. 2017; Freeman, Duguma, and Minang 2015). In a recent review, Reed et al. (2016) identify a large number of terms from the literature that refer to some sort of integrated landscape approach, with "every new tweaking of a given iteration resulting in a plethora of often florid and confusing terms" (Reed et al. 2016, 2542). Each new attempt to define or re-define a landscape approach potentially adds to the confusion as to what is needed for landscape management, emphasising the need for a framework to better identify and evaluate underlying elements of programmes and projects using the concept.

Reed et al. $(2016,2544)$ define their 'landscape approach' as "a framework to integrate policy and practice for multiple competing land uses through the implementation of adaptive and integrated management systems". The term landscape approach is often used interchangeably with 'ecosystem approach' (e.g. (Convention on Biological Diversity 2007; Sayer, Maginnis, and Laurie 2005; Shepherd 2008; Smith and Maltby 2003) to describe any effort to address conservation and development at the same time. Other uses of the term refer more narrowly to spatial planning or modelling of biophysical elements to the landscape, but these are generally not integrated approaches. Freeman et al. $(2015,1)$ argued that "more focus needs to be placed on the process of taking the approach" and highlighted the importance of multifunctionality, transdisciplinarity, participation, complexity, and sustainability.

Integrated landscape approaches have been characterised as 'boundary concepts' open to a wide range of interpretations, which makes it appealing to a broad range of actors (McCall 2016; Opdam et al. 2013). But the same ambiguity is also a potential disadvantage, as it can be used to claim that any effort at management is a landscape approach regardless of aims, values or outcomes (Nielsen 2016; Sayer et al. 2017). This lack of clear definitions and theoretical frameworks is a barrier to implementing and evaluating integrated landscape approaches (Erbaugh and Agrawal 2017; Reed et al. 2017; Waylen et al. 2014). Guidelines and implementation pathways are often developed and applicable in a specific project context (Angelstam et al. 2019; Sayer et al. 2017), despite efforts to create more general principles and guidelines (Sayer et al. 2013; Convention on Biological Diversity 2007), Reed et al. (2017, 481) note that landscape approaches "remain nascent in both their conceptualization and implementation". To address this gap, this paper builds a three pillar framework for integrating forest management across a landscape, to guide implementation and evaluation of integrated landscape approaches in a range of tropical forest contexts. The framework builds upon and synthesises existing landscape management guidelines, approaches and principles and is also likely to be applicable to other landscapes. 


\section{Elements of Integrated Landscape Approaches - Disciplines, Practices and Activities}

In seeking a framework to guide and support implementation of more integrated forest management, this paper firstly seeks to re-analyse integrated landscape approaches by considering the elements that underpin such approaches through an analysis of the literature of landscape-based concepts. This seeks to identify important and common components for implementing for such approaches, instead of trying to review each of the large number of terms and definitions.

Our analysis of the literature initially sought out disciplines, activities and practices related to forest conservation and management that are explicitly applied at a landscape-level. However, the analysis revealed a number of concepts that implicitly operate at a landscape scale but are not called landscape approaches, and hence the analysis was broadened to disciplines, practices and activities that broadly seek to study, understand or improve the management of forest ecosystems and their services in place. Many of these elements are applicable to non-forested landscapes and draw on the literature accordingly. As discussed below, this potentially broadens the applicability of our framework beyond forests.

In attempting to take a more integrated and holistic approach at a landscape level, landscape approaches draw upon and a number of different fields, that themselves cross academia and practice, including ecology, governance, planning and design (see e.g. (Albert et al. 2014; Beunen and Opdam 2011; Buizer, Arts, and Westerink 2016; Görg 2007; Selman 2005; Selman 2009).

Landscape ecology is a well-established discipline that examines the biophysical and ecological structures and functions of landscapes and how management can both harness the services ecosystems provide and maintain the integrity of the ecosystems (Mori, Lertzman, and Gustafsson 2017; Musacchio 2013). It is also concerned with providing tools to ensure that understanding and knowledge of ecosystems is used to inform management and land use decisions (Opdam et al. 2013; Watts et al. 2017) and often provides the framework for ecosystem and landscape approaches and management discussions (Freeman, Duguma, and Minang 2015; Musacchio 2013; Lindenmayer and Cunningham 2013).

Landscape governance (see e.g. Beunen and Opdam 2011; Buizer, Arts, and Westerink 2016; Görg 2007) draws on the much broader governance literature to examine the interactions between stakeholders in decision-making, policy and politics at the landscape scale. This literature highlights how governance failures can be responsible for landscape degradation and over-exploitation and proposes forms of bottom-up governance that can support forest conservation and sustainable development (Tim Cadman 2012; Lockwood et al. 2010; Nagendra and Ostrom 2012). In addition, the literature on governance of common pool resources is likely to be relevant. Although this focuses on natural resources and is not explicitly about the landscape-scale, these resources stem from ecosystems and their services and are managed in place across a shared landscape, as highlighted by Ostrom's original examples (Ostrom 1990). 
Landscape planning is a practice that seeks to combine the knowledge of the biophysical from landscape ecology with the socio-political elements of the governance arrangements, and turn this knowledge and values into action (see e.g. (Dramstad and Fjellstad 2011; Matthews and Selman 2006; Selman 2005; Selman 2009; Valencia-Sandoval, Flanders, and Kozak 2010). Whereas traditional land use planning is more anthropocentric, bioregional planning has an ecological focus, using biophysical and ecological spatial scales (bioregions) to try and better align human uses and values to the biophysical environment (Brunckhorst 2013).

Landscape design is a planning-related, but more practice-oriented element of integrated landscape approaches. Forest landscape design is a process for developing a targeted landscape pattern to meet societal goals and ecological needs (Diaz 1992; Mladenoff et al. 1994; Lindenmayer and Hobbs 2008; Bell and Apostol 2007). It is suggested as a way to bridge the implementation gap (Bartuszevige et al. 2016) by linking the desired outcomes based on planning of the landscape, including consideration of ecosystem structure and functions with the choices about the pattern of the landscape, including composition (types of trees) and structure (e.g. matrices, patches, corridors) (Diaz 1992; Mladenoff et al. 1994; Lindenmayer and Hobbs 2008; Bell and Apostol 2007).

Implementation of landscape planning and design in a forest context can include forest landscape restoration (Erbaugh and Oldekop 2018; IUCN and WRI 2016) to restore certain structures and functions of the landscape after significant disruption from human actions, often to support other human uses (Menz, Dixon, and Hobbs 2013). Landscape conservation focuses on a way to maintaining and protecting the ecological elements of landscapes (Baldwin et al. 2018; Curtin and Tabor 2016). These approaches to action on the ground are related to a broader literature around natural resource management (NRM), which uses ecological scientific knowledge to understand the natural processes and the governance literature that considers how people interact with these natural resources (Lockwood et al. 2010). These activities are closer to practice, and provide key tools for implementing action on the ground.

These disciplines, practices and activities overlap significantly but can be mapped by the extent to which they address policy or implementation, and whether they focus on the human (socioeconomic) or natural (ecological) characteristics of the landscape (Figure 2). 


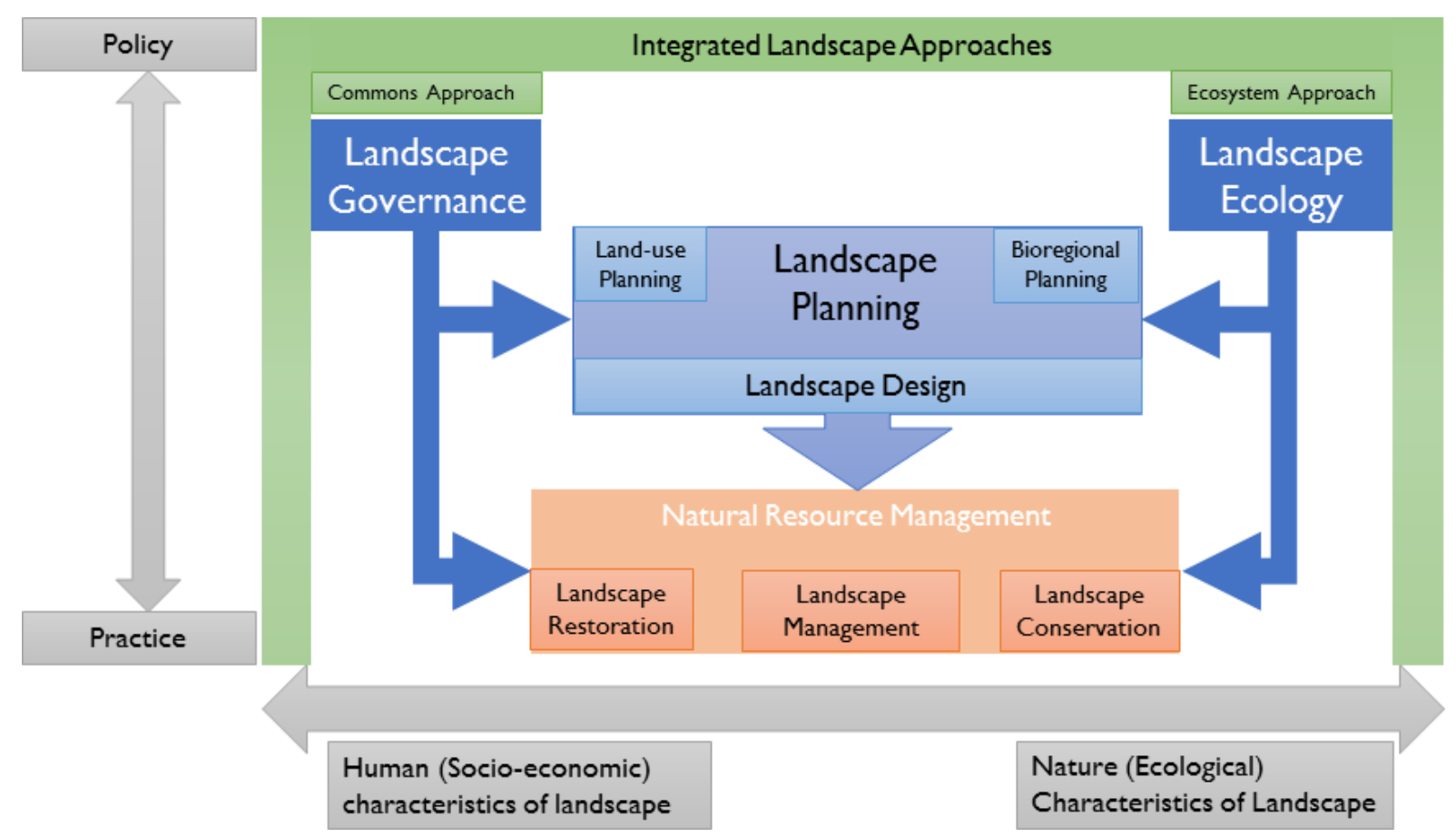

Figure 2: Mapping of disciplines, practices and activities that are concerned with understanding or improving the management of ecosystems and their services in place. Collectively, these elements all contribute to our understanding of what constitutes integrated landscape approaches. The elements are defined and discussed in Section 3 and are mapped here according to whether (1) their focus is more policy or practice based and (2) they consider the landscape through a socio-economic or ecological characteristics lens. Mapping the relationships was the first step in the development of our proposed framework.

In seeking a framework, we focus on the policy-level elements, which can be used to guide the more practice-oriented activities. We suggest that there are three key theoretical components that underpin integrated landscape approaches: (1) the importance of ecosystem structure and function, or ecosystem integrity, from landscape ecology and knowledge of ecosystems it provides; (2), the importance of governance for sustainability at both the policy level (Adger et al. 2003; Buizer, Arts, and Westerink 2016; Tim Cadman 2012) and within NRM (Lockwood et al. 2010); and (3) planning as a process to integrate social and ecological knowledge and values (Matthews and Selman 2006; Selman 2005; Selman 2009). The next sections build a framework from these theoretical components through an analysis and synthesis of three key sets of principles relevant to integrated landscape approaches.

\section{Re-analysisng Integrated Landscape Approach Principles}

This section further develops a framework based on the three components identified above planning, governance and ecosystem integrity - by analysing the implementation of three wellestablished sets of principles for integrated landscape approaches in the context of tropical forest landscapes.

The highly context-specific nature of landscapes means that general guidance for implementation of integrated landscape approaches is largely limited to sets of principles (Sayer et al. 2013; Convention on Biological Diversity 2007). These principles have also been 
criticised for being too broad, difficult to implement and adding to the list of jargon (Erbaugh and Agrawal 2017; Waylen et al. 2014). Nonetheless, such principles provide ways to test, identify and define integrated landscape approaches and their implementation. Here, three common sets of principles that are relevant to implementing integrated landscape approaches are analysed to guide the development of the framework. We note that other important principles could be developed from issues discussed in the literature, e.g. recent studies have highlighted ambiguity as an important challenge (Brugnach and Ingram 2012). The principles chosen here represent integrated landscape approaches that are among the most commonly cited in the literature, and have been widely applied and discussed in forest contexts (Sayer, Maginnis, and Laurie 2005; Nagendra and Ostrom 2012; Nielsen 2016). Following Sayer's discussion in proposing the landscape approach principles (Sayer et al. 2013), each set of principles is analysed by identifying the barriers, needs and opportunities that arise from implementing them in a tropical forest landscape context, based on existing discussions and experience in implementing applied research projects across multiple tropical landscape contexts. In this way, we seek to strengthen the utility of the framework by considering the application of these principles in real world settings. They also cover the three important components of integrated landscape approaches identified above. The ecosystem approach principles, defined by the CBD, as its name suggests, places ecosystems at the centre. Ostrom's principles for common pool resources focus on institutional and governance arrangements. Sayer's landscape approach principles aim to be comprehensive, but are developed with a strong practice-oriented focus, which provides clear links to planning.

\subsection{The Landscape Approach Principles}

Sayer et al. (2013) proposed ten principles of a landscape approach (herein 'LA principles') that focused on practical actions, such as adaptive management and participatory approaches (Table 1). The principles were developed based on current approaches and statements of "good practice" and on an extensive multidisciplinary consultation with a range of practitioners, including in forest landscape management. Building on Sayer's original discussion (Sayer et al. 2013), consideration of the implementation of the principles in tropical forest landscapes suggest a range of challenges, needs and opportunities (Table 1).

The LA principles reflect the complexity and uncertainty that are inherent in landscapes and create challenges for management: landscape processes, both social and ecological, occur on multiple scales (LA3) and consist of multifunctional ecosystems and social systems (LA4). Similarly, calls for resilience (LA9) reflect a complex socio-ecological systems view of landscapes (Folke et al. 2010). Implementing these principles is hindered by limited knowledge of these landscape systems and their interactions, as well as limited opportunities for knowledge to be shared across sectors because different sectors 'know too differently' (Brugnach et al. 2008).

Relatedly, the first LA principle calls for continual learning and adaptive management, which recognises the need to manage change and continuing development of knowledge about the landscape. This requires an ongoing process for gathering and sharing knowledge, ensuring shared learning and making decisions about actions and monitoring the outcomes of those 
actions (Holling 1978). A common concern entry point (LA2) can provide an important mechanism for guiding this process of negotiated processes and is important in planning processes. The need knowledge and learning is also important for effective participatory monitoring (LA8).

Several principles require the involvement of multiple stakeholders, including communities, in decision-making, implementation and monitoring (LA5, LA6 and LA8). LA7 requires legitimate governance arrangements that are respected, especially in areas where forests are under threat from illegal extractive logging and mining (Schwartzman and Zimmerman 2005; Tyukavina et al. 2017; Nelson et al. 2014; Filer 2012). Participatory processes might have a role to play here, although in these contexts, land rights and enforcement of these rights will also be important (Bebbington et al. 2018; Notess et al. 2018). Importantly, LA10 recognises that improved knowledge, learning and greater participation all require strengthened stakeholder capacity, which is often limited in these forest landscapes (Bush, Kermarc, and Zambo 2015; McNamara et al. 2018). Hence, implementing these principles needs processes, as well as resources, that will build capacity.

The LA principles highlight the importance of knowledge, shared learning and participation to manage change. Landscapes are often considered to be static states but change is an inherent of a landscape system (Tress and Tress 2001). Forest landscape systems, like all landscapes. are linked to other local, global and regional systems at a range of scales (Martín-López et al. 2019). 
Table 1: Challenges, needs and opportunities for implementing the landscape approach principles of Sayer et al. (2013).

\begin{tabular}{|c|c|c|}
\hline Landscape Approach Principles & Challenges & Needs and Opportunities \\
\hline $\begin{array}{l}\text { LAI. Continual learning and adaptive } \\
\text { management }\end{array}$ & $\begin{array}{l}\text { - Limited scientific knowledge } \\
\text { - Limited knowledge sharing } \\
\text { - Limited evaluation }\end{array}$ & $\begin{array}{l}\text { - Need for improved and ongoing scientific assessment } \\
\text { - Need for shared learning processes } \\
\text { - Need for monitoring, evaluation and feedback } \\
\text { - Opportunity for participatory and deliberative approaches }\end{array}$ \\
\hline LA2. Common concern entry point & - Multiple stakeholders with a range of concerns & - Need for development of shared objectives \\
\hline LA3. Multiple scale & $\begin{array}{l}\text { - Limited scientific knowledge } \\
\text { - Limited coordination between levels of government and } \\
\text { management } \\
\text { - Limited capacity for coordination and integration }\end{array}$ & $\begin{array}{l}\text { - Need for spatial scientific knowledge } \\
\text { - Need for shared learning processes } \\
\text { - Opportunity for improved coordination and integration }\end{array}$ \\
\hline LA4. Multifunctionality & $\begin{array}{l}\text { - Limited knowledge and understanding of multiple functions of } \\
\text { landscape ecosystems and their interactions } \\
\text { - Multiple functions can result in potential trade-offs in land use } \\
\text { choices }\end{array}$ & $\begin{array}{l}\text { - Need for improved and ongoing scientific assessment of } \\
\text { ecosystems } \\
\text { - Need for shared learning processes } \\
\text { - Need for process to help choose trade-offs }\end{array}$ \\
\hline LA5. Multiple stakeholder & $\begin{array}{l}\text { - Many stakeholders with significant power imbalances } \\
\text { - Participatory processes are challenging, resource intensive and } \\
\text { time consuming }\end{array}$ & $\begin{array}{l}\text { - Need and opportunity for participatory and deliberative } \\
\text { processes }\end{array}$ \\
\hline $\begin{array}{l}\text { LA6. Negotiated and transparent change } \\
\text { logic }\end{array}$ & $\begin{array}{l}\text { - Limited, centralised planning and policy } \\
\text { - Focus on development and economic growth }\end{array}$ & $\begin{array}{l}\text { - Need for agreed goals } \\
\text { - Need for good governance } \\
\text { - Opportunity for participatory and deliberative processes }\end{array}$ \\
\hline $\begin{array}{l}\text { LA7. Clarification of rights and } \\
\text { responsibilities }\end{array}$ & $\begin{array}{l}\text { - Limited legitimacy } \\
\text { - External pressures on land use } \\
\text { - Risk of illegitimate land uses }\end{array}$ & $\begin{array}{l}\text { - Need for agreed objectives } \\
\text { - Need for agreed rights and responsibilities } \\
\text { - Opportunity for participatory and deliberative processes }\end{array}$ \\
\hline $\begin{array}{l}\text { LA8. Participatory and user friendly } \\
\text { monitoring }\end{array}$ & $\begin{array}{l}\text { - Landscape will require wide-range of monitoring } \\
\text { - Limited capacity to carry out monitoring } \\
\text { - Behaviour of (external) stakeholders not being monitored }\end{array}$ & $\begin{array}{l}\text { - Need for knowledge of resource condition. } \\
\text { - Need for agreed and legitimate rules }\end{array}$ \\
\hline LA9. Resilience & $\begin{array}{l}\text { - Limited knowledge of ecosystem structure, function and limits } \\
\text { - Risk of tipping points } \\
\text { - High vulnerability due to poverty and limited capacity }\end{array}$ & $\begin{array}{l}\text { - Need for consideration of ecosystem integrity in objectives } \\
\text { - Opportunity to build resilience through alternative } \\
\text { development pathways }\end{array}$ \\
\hline LAI0. Strengthened stakeholder capacity & - Limited capacity & $\begin{array}{l}\text { - Opportunity to build capacity through stakeholder } \\
\text { participation and deliberation }\end{array}$ \\
\hline
\end{tabular}




\subsection{Ecosystem Approach Principles}

The Ecosystem Approach was formally endorsed by the fifth Conference of the parties to the Convention on Biological Diversity (CBD) in May 2000. Some recent discussions on applying ecosystem approach in forests use the words ecosystems and landscapes more or less interchangeably (Sayer, Maginnis, and Laurie 2005; Smith and Maltby 2003). The ecosystem approach is an integrated approach designed to be the meeting point between sustainable development and poverty alleviation (Smith and Maltby 2003). The approach is defined by 12 principles (Convention on Biological Diversity 2007) (see Table 2). The approach also consists of four guidelines that stem directly from the principles, which are not discussed explicitly, but the analysis shows close links to the guidelines.

The first EA principle highlights that the objectives of natural resource management, which directly affect ecosystem services, are about societal choices. Hence, knowledge and understanding of those ecosystems, the objectives that are chosen and how those choices are made are fundamental (Shepherd 2008). The ecosystem approach recognises that the benefits and costs of using natural resources need to be accounted for (EA4) and uses balanced within (EA 10) and between (EA3) ecosystems. Achieving this requires knowledge of these systems and processes of choosing trade-offs and integrating and coordinating decision-making across the multiple sectors that affect ecosystems (Ianni and Geneletti 2010).. This also requires economic evaluations of ecosystems services, which risks their commodification and being treated as fungible assets, but also opens up opportunities for development pathways based on carbon finance and other such ecosystem service payments (Shackleton et al. 2017; Sitas et al. 2014; Vincent 2012).

The need for long-term management objectives (EA8) requires long term planning of the landscape. The principles also recognise the need for combining a wide array of knowledge, including scientific and indigenous and local knowledge (EA11), although this is not straightforward. Indigenous and local knowledge is often ignored in technocratic policymaking settings, missing the opportunity for important synergies to be realised (Mackey and Claudie 2015). Deliberative and participatory processes can be a way to combine and use a wide variety of knowledge, linking to the need for participation of all relevant sectors (EA12) (Berkes 2009; Selman 2004).

The ecosystem approach, as its name suggests, strongly focuses on the impacts on and relationships between ecosystems (EA3, EA5, EA6) and between ecosystems and resource users (EA1, EA3, EA8 and EA10). This requires knowledge of the structure and function of these ecosystems and how they interact, as well as knowledge of impacts and changes caused by resource use. Importantly, the principles recognise the need for sharing that knowledge with stakeholders and using it as the basis for decision-making. The EA and LA principles demonstrate considerable overlap, emphasising the importance of recognising change and calling for long term objective setting, adaptive management, learning and participation. However, the EA approach has less explicit focus on the importance of rights and responsibilities. 
Table 2: Challenges, needs and opportunities for implementing the Ecosystem Approach Principles

\begin{tabular}{|c|c|c|}
\hline Ecosystem Approach Principles & Challenges & Needs and Opportunities \\
\hline $\begin{array}{l}\text { EAI. The objectives of management of } \\
\text { land, water and living resources are a } \\
\text { matter of societal choices }\end{array}$ & $\begin{array}{l}\text { - Resources are varied, shared across the landscape and are } \\
\text { interdependent } \\
\text { - Limited consideration of impacts of economic development } \\
\text { - Risk of 'tragedy of the commons' }\end{array}$ & $\begin{array}{l}\text { - Need for process to make impacts of societal choices } \\
\text { clear } \\
\text { - Need for shared objectives } \\
\text { - Need for participation and deliberation } \\
\text { - Opportunity to apply common pool resource } \\
\text { approach }\end{array}$ \\
\hline $\begin{array}{l}\text { EA2. Management should be decentralized } \\
\text { to the lowest appropriate level }\end{array}$ & $\begin{array}{l}\text { - Forest ownership is at community-level, policy tends to be } \\
\text { at a higher provincial/government level } \\
\text { - Capacity is limited, especially at more local levels } \\
\text { - Unclear what the most 'appropriate' level is - different } \\
\text { natural resources may have different lowest appropriate } \\
\text { levels }\end{array}$ & $\begin{array}{l}\text { - Need for integration } \\
\text { - Need for capacity at lower levels } \\
\text { - Need for greater coordination between levels } \\
\text { - Opportunity for greater community involvement } \\
\text { based on traditional approaches }\end{array}$ \\
\hline $\begin{array}{l}\text { EA3. Ecosystem managers should consider } \\
\text { the effects (actual or potential) of their } \\
\text { activities on adjacent and other } \\
\text { ecosystems. }\end{array}$ & $\begin{array}{l}\text { - Limited knowledge of ecosystems and their interactions } \\
\text { - Limited coordination between stakeholders across } \\
\text { ecosystems } \\
\text { - Ecosystems cross political and ownership boundaries }\end{array}$ & $\begin{array}{l}\text { - Need for improved ecosystem knowledge } \\
\text { - Need for better knowledge sharing } \\
\text { - Need for greater coordination } \\
\text { - Need for integrated approaches to natural resources }\end{array}$ \\
\hline $\begin{array}{l}\text { EA4. Recognizing potential gains from } \\
\text { management, there is usually a need to } \\
\text { understand and manage the ecosystem in } \\
\text { an economic context }\end{array}$ & $\begin{array}{l}\text { Economic value of ecosystem services, especially cultural } \\
\text { services, not accounted for } \\
\text { - Limited effort to internalise costs of extractive uses e.g. } \\
\text { logging }\end{array}$ & $\begin{array}{l}\text { - Need for ecosystem economic evaluations } \\
\text { - Opportunity for development pathways that include } \\
\text { valuation of ecosystems and culture }\end{array}$ \\
\hline $\begin{array}{l}\text { EA5. Conservation of ecosystem structure } \\
\text { and functioning, in order to maintain } \\
\text { ecosystem services, should be a priority } \\
\text { target of the ecosystem approach }\end{array}$ & $\begin{array}{l}\text { - Ecosystems structure and function rarely included in } \\
\text { objectives and goals } \\
\text { - Limited stakeholder knowledge of ecosystem structure and } \\
\text { function }\end{array}$ & $\begin{array}{l}\text { - Need for improved ecosystem knowledge } \\
\text { - Need for monitoring and evaluation of ecosystems } \\
\text { - Need for processes to share knowledge } \\
\text { - Opportunity for inclusion of ecosystems in goals and } \\
\text { objectives at community level, harnessing cultural } \\
\text { knowledge and values }\end{array}$ \\
\hline $\begin{array}{l}\text { EA6. Ecosystem must be managed within } \\
\text { the limits of their functioning }\end{array}$ & $\begin{array}{l}\text { - Assessment of limits is challenging } \\
\text { - Risk of tipping points } \\
\text { - All stakeholders need to understand and agree limits }\end{array}$ & $\begin{array}{l}\text { - Need for improved and ongoing scientific assessment } \\
\text { - Need for flexible and adaptive approaches } \\
\text { - Opportunity to include ecosystem integrity as an } \\
\text { objective }\end{array}$ \\
\hline $\begin{array}{l}\text { EA7. The ecosystem approach should be } \\
\text { undertaken at the appropriate spatial and } \\
\text { temporal scales }\end{array}$ & $\begin{array}{l}\text { - Unclear as to what the appropriate scale is } \\
\text { - Limited long term planning } \\
\text { - Pressure of immediate development needs encourages short } \\
\text { term approach }\end{array}$ & $\begin{array}{l}\text { - Need for spatial scientific knowledge } \\
\text { - Need for shared learning processes } \\
\text { - Need for long term planning }\end{array}$ \\
\hline
\end{tabular}




\begin{tabular}{|c|c|c|}
\hline & & $\begin{array}{l}\text { - Opportunity for development that supports } \\
\text { ecosystems }\end{array}$ \\
\hline $\begin{array}{l}\text { EA8. Recognizing the varying temporal } \\
\text { scales and lag-effects that characterize } \\
\text { ecosystem processes, objectives for } \\
\text { ecosystem management should be set for } \\
\text { the long term }\end{array}$ & $\begin{array}{l}\text { - Limited long term planning } \\
\text { - Pressure of immediate development needs encourages short } \\
\text { term approach }\end{array}$ & $\begin{array}{l}\text { - Need for improved and ongoing scientific assessment } \\
\text { - Need for shared learning processes } \\
\text { - Need for long term planning } \\
\text { - Opportunity for development that supports } \\
\text { ecosystems }\end{array}$ \\
\hline $\begin{array}{l}\text { EA9. Management must recognize that } \\
\text { change is inevitable }\end{array}$ & - Tendency to assume 'stationarity' & $\begin{array}{l}\text { - Need for learning } \\
\text { - Need to manage change (planning) } \\
\text { - Need for adaptive approaches }\end{array}$ \\
\hline $\begin{array}{l}\text { EAI0. The ecosystem approach should } \\
\text { seek the appropriate balance between, } \\
\text { and integration of, conservation and use } \\
\text { of biological diversity }\end{array}$ & $\begin{array}{l}\text { - Unclear what the 'appropriate' balance is in any given } \\
\text { context } \\
\text { - Focus on economic development in policy and planning }\end{array}$ & $\begin{array}{l}\text { - Need for shared understanding of ecosystems and } \\
\text { landscape } \\
\text { - Need for shared and agreed objectives and activities } \\
\text { - Opportunity for deliberative and participatory } \\
\text { planning }\end{array}$ \\
\hline $\begin{array}{l}\text { EAII. The ecosystem approach should } \\
\text { consider all forms of relevant information, } \\
\text { including scientific and indigenous and } \\
\text { local knowledge, innovations and practices }\end{array}$ & $\begin{array}{l}\text { - Limited scientific knowledge } \\
\text { - Local and traditional knowledge rarely recognised in formal } \\
\text { processes }\end{array}$ & $\begin{array}{l}\text { - Need for shared learning processes } \\
\text { - Opportunity for participatory and deliberative } \\
\text { approaches }\end{array}$ \\
\hline $\begin{array}{l}\text { EAI2. The ecosystem approach should } \\
\text { involve all relevant sectors of society and } \\
\text { scientific disciplines }\end{array}$ & $\begin{array}{l}\text { - Participatory processes are challenging, resource intensive } \\
\text { and time consuming }\end{array}$ & $\begin{array}{l}\text { - Need for shared learning processes } \\
\text { - Opportunity for participatory and deliberative } \\
\text { approaches }\end{array}$ \\
\hline
\end{tabular}




\subsection{Common Pool Resource Principles}

Landscape ecosystems and the services they provide are shared across a landscape, with access to these services difficult to control. Hence, landscapes fit the definition of common pool resources (CPRs) provided by Gardner, Ostrom and Walker as: "a resource system, whose size or characteristics makes it costly, but not impossible, to exclude potential beneficiaries from obtaining benefits from its use" (Gardner, Ostrom, and Walker 1990, 335).

Ostrom (1990) argued that "getting the institutions right" is of paramount importance in managing CPRs (p.11) and identified eight key principles for managing common pool resources (see Table 3 Ostrom focuses on natural resources but the availability of natural resources is determined by interactions between ecosystem services and resource users (Barnaud et al. 2018), and CPR principles and ideas have been shown to be applicable to tropical forest landscapes (Agrawal, Chhatre, and Hardin 2008; Nagendra and Ostrom 2012; Zimmerman et al. 2001).

Ostrom's first two principles (CPR1 and 2) require defining boundaries, of both the CPR itself and the users, and then linking rules to the local conditions are challenging in landscapes of multiple interconnected ecological, social and cultural sub-systems. Social and cultural systems boundaries rarely align to ecological or biophysical boundaries (Martín-López et al. 2019). Also, existing social boundaries may be informal and contested, and thus political and controversial (Filer 2012). Hence, these principles require scientific and local knowledge of the ecosystems and social systems, processes for sharing of that knowledge among stakeholders and methods to achieve agreement.

CPR 3 and 4 concern the need for decision-making and monitoring that are defined and implemented by those affected by the rules. A focus on the resource users in tropical forest landscapes emphasises the need for local communities that depend on and manage the forest to be involved in rule-making (Agrawal, Chhatre, and Hardin 2008; Maraseni et al. 2014; Tavares et al. 2014). In many cases informal rules for resource management will already exist in these landscapes, and have been successful in maintaining the communities for centuries. CPR 5 and 6 highlight the need for monitoring and conflict resolution, and again emphasise that there is a need to ensure those within the landscape are involved, and have the capacity and power to implement monitoring and sanctions.

CPR 7 and 8 are about ensuring that the rules for governing the system are recognised and respected by those outside the system and are part of a nested governance system that is consistent. As has been noted elsewhere, Ostrom's focus was on internal resource rules and processes (Agrawal 2014; Cox, Arnold, and Villamayor Tomás 2010), but forest landscapes are linked to other systems (biophysical and sociocultural) and are influenced by multiple stakeholders and processes at local, regional and global scales. Hence, consideration of power dynamics and creating rules that are respected and considered legitimate are important, especially where landscapes are highly contested. 
Table 3: The Challenges, needs and opportunities for implementing Ostrom's design principles for forest landscapes.

\begin{tabular}{|c|c|c|}
\hline Ostrom's Design Principles & Challenges & Needs and Opportunities \\
\hline $\begin{array}{l}\text { CPRI. Clearly defined boundaries } \\
\text { Defined boundaries of resources and over } \\
\text { withdrawal rights of users }\end{array}$ & $\begin{array}{l}\text { - Defining landscape and ecological system boundaries is } \\
\text { difficult due to uncertainty and complexity. } \\
\text { - Social, i.e. political and cultural boundaries will already exist } \\
\text { and challenging them can be difficult. }\end{array}$ & $\begin{array}{l}\text { - Need for improved scientific knowledge } \\
\text { - Need for better inclusion of local knowledge } \\
\text { - Need to develop shared knowledge and understanding of } \\
\text { landscape } \\
\text { Opportunity to use existing local and traditional } \\
\text { knowledge }\end{array}$ \\
\hline $\begin{array}{l}\text { CPR2. Congruence between } \\
\text { appropriation and provision rules and } \\
\text { local conditions } \\
\text { Match rules governing use of common goods } \\
\text { to local needs and conditions }\end{array}$ & $\begin{array}{l}\text { - Complexity of landscape scale means there will be many } \\
\text { interacting resource uses that need to be understood. } \\
\text { - Changing local needs and conditions (system change) due to } \\
\text { range of factors, e.g. economic development, population } \\
\text { growth, climate change. }\end{array}$ & $\begin{array}{l}\text { - Need for improved knowledge of ecological and social } \\
\text { systems within landscape } \\
\text { - Need for better use of local knowledge. } \\
\text { - Need for learning and adaptive process }\end{array}$ \\
\hline $\begin{array}{l}\text { CPR3. Collective-choice arrangements } \\
\text { Ensure that those affected by the rules can } \\
\text { participate in modifying the rules }\end{array}$ & $\begin{array}{l}\text { - Complexity of landscape scale requires rules agreed across } \\
\text { different resource uses (sectors). } \\
\text { - Limited capacity to ensure participation } \\
\text { - Existing rules governing communities and resources under } \\
\text { pressure from external and internal changes. }\end{array}$ & $\begin{array}{l}\text { - Need to provide capacity and ensure that a wide range of } \\
\text { stakeholders across the landscape, including communities } \\
\text { living in the landscape, are involved in decision-making } \\
\text { - Need for shared and agreed objectives and activities }\end{array}$ \\
\hline $\begin{array}{l}\text { CPR4. Monitoring } \\
\text { Develop a system, carried out by community } \\
\text { members, for monitoring members' behaviour } \\
\text { and resource condition }\end{array}$ & $\begin{array}{l}\text { - Landscape system will require a wide-range of monitoring } \\
\text { - Capacity to carry out monitoring can be limited. } \\
\text { Behaviour of other external stakeholders not being } \\
\text { monitored }\end{array}$ & $\begin{array}{l}\text { - Need for knowledge of resource condition } \\
\text { - Rules need to be seen as legitimate by ensuring } \\
\text { participation in developing rules }\end{array}$ \\
\hline $\begin{array}{l}\text { CPR5. Graduated sanctions } \\
\text { Use graduated sanctions for rule violators }\end{array}$ & $\begin{array}{l}\text { - Limited power at community level to impose sanctions, } \\
\text { especially on users from outside the landscape system. }\end{array}$ & $\begin{array}{l}\text { - Need for rules to be seen as legitimate. } \\
\text { - Need for power to impose sanctions at appropriate level }\end{array}$ \\
\hline $\begin{array}{l}\text { CPR6. Conflict-resolution mechanisms } \\
\text { Provide accessible, low-cost means for dispute } \\
\text { resolution }\end{array}$ & $\begin{array}{l}\text { - Multifunctionality of landscape systems means wide range of } \\
\text { stakeholders will be involved. } \\
\text { - Disputes with powerful external users, e.g. logging } \\
\text { companies, can be difficult to resolve. }\end{array}$ & $\begin{array}{l}\text { - Need to develop legitimate grievance procedures that are } \\
\text { respected by all resource users. }\end{array}$ \\
\hline $\begin{array}{l}\text { CPR7. Minimal recognition of rights to } \\
\text { organize Make sure the rule-making rights of } \\
\text { community members are respected by outside } \\
\text { authorities }\end{array}$ & $\begin{array}{l}\text { - Rights not always observed by external stakeholders. } \\
\text { - Limited capacity to protect those existing rights, which are } \\
\text { often fragile. }\end{array}$ & $\begin{array}{l}\text { - Need to ensure internal rules and decision-making are } \\
\text { seen as legitimate and respected by governments and } \\
\text { external stakeholders. }\end{array}$ \\
\hline $\begin{array}{l}\text { CPR8. Nested enterprises } \\
\text { Build responsibility for governing the common } \\
\text { resource in nested tiers from the lowest level } \\
\text { up to the entire interconnected system }\end{array}$ & - Common, related and agreed rules are needed at all levels & $\begin{array}{l}\text { - Need for nested governance that aligns rules across } \\
\text { scales } \\
\text { - Need for rules at different scales, including local scale, to } \\
\text { be seen as legitimate } \\
\text { - Need to build trust at all levels }\end{array}$ \\
\hline
\end{tabular}


Ostrom's CPR principles focus on institutions and they share the emphasis on participation and collaboration with the EA and LA principles. Implementing the principles requires knowledge and knowledge sharing, and processes for agreeing shared goals. Notably, these principles have limited focus on change, and Ostrom's case studies drew on landscapes that had maintained their resources provisions, implying stability of their ecosystem structure and function, for significant periods. However, changing resource demands creates new pressures and drivers, and processes to manage change can be important.

\section{Synthesis: Key Pillars for Integrating Forest Management Across the Landscape}

Table 4 presents a synthesis of the key needs identified from the analysis of the principles above. These needs can be grouped together as elements of ecosystem integrity, effective planning and strong governance; noting that there is significant overlap between them. A more detailed mapping of every principle to the three key pillars is provided in Fig. S1 in the supplementary material as an analytical model.

Table 4: Overlap and differences between principles based on needs and opportunities and how they align to the three key pillars of ecosystem integrity, effective planning and strong governance. Stronger colours show greater focus on particular needs.

\begin{tabular}{|c|c|c|c|c|c|c|}
\hline & $\begin{array}{l}\text { Landscape } \\
\text { Approach }\end{array}$ & $\begin{array}{l}\text { Ecosystem } \\
\text { Approach }\end{array}$ & $\begin{array}{l}\text { Common Pool } \\
\text { Resources }\end{array}$ & & & \\
\hline $\begin{array}{l}\text { Effective ecosystem } \\
\text { structure and function }\end{array}$ & LA4, LA9 & $\begin{array}{l}\text { EA6, EA5, } \\
\text { EA8 }\end{array}$ & & \multirow{5}{*}{ 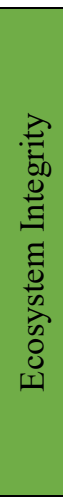 } & & \\
\hline $\begin{array}{l}\text { Knowledge of ecosystems } \\
\text { and other landscape systems }\end{array}$ & LA4, LA9 & $\begin{array}{l}\text { EA3, EA5, } \\
\text { EA6, EA7, } \\
\text { EA8, EA10 }\end{array}$ & CPR1 & & & \\
\hline Monitoring and evaluation & LA1, LA8 & $\begin{array}{l}\text { EA3, EA5, } \\
\text { EA6, EA9 }\end{array}$ & CPR3 & & \multirow{9}{*}{ 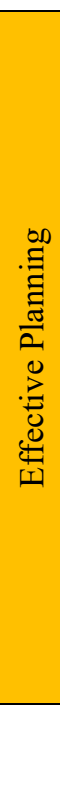 } & \\
\hline $\begin{array}{l}\text { Adaptive and long term } \\
\text { management }\end{array}$ & LA1 & $\begin{array}{l}\text { EA7, EA8, } \\
\text { EA9 }\end{array}$ & CPR2 & & & \\
\hline $\begin{array}{l}\text { Shared knowledge and } \\
\text { learning }\end{array}$ & LA1, LA4 & $\begin{array}{l}\text { EA3, EA6, } \\
\text { EA8, EA9, } \\
\text { EA11, EA12 }\end{array}$ & CPR1, CPR2 & & & \\
\hline $\begin{array}{l}\text { Economic evaluation of } \\
\text { ecosystems }\end{array}$ & & EA4, EA10 & & \multirow{6}{*}{\multicolumn{2}{|c|}{ 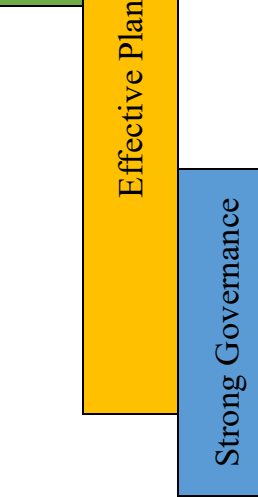 }} & \\
\hline Agreed objectives and goals & $\begin{array}{l}\text { LA2, LA6, } \\
\text { LA7, LA9 }\end{array}$ & EA1, EA8 & CPR2, CPR8 & & & \\
\hline $\begin{array}{l}\text { Coordination and } \\
\text { integration }\end{array}$ & $\begin{array}{l}\text { LA3, LA6, } \\
\text { LA7 }\end{array}$ & $\begin{array}{l}\text { EA3, EA7, } \\
\text { EA10 }\end{array}$ & CPR8 & & & \\
\hline $\begin{array}{l}\text { Agreed rights and } \\
\text { responsibility }\end{array}$ & LA6, LA7 & EA2 & $\begin{array}{l}\text { CPR1, CPR2, } \\
\text { CPR7, CPR8 }\end{array}$ & & & \\
\hline Participation & $\begin{array}{l}\text { LA5, LA6, } \\
\text { LA8, LA10 }\end{array}$ & EA11, EA12 & $\begin{array}{l}\text { CPR2, CPR3, } \\
\text { CPR7 }\end{array}$ & & & \\
\hline $\begin{array}{l}\text { Sanctions and conflict } \\
\text { resolution processes }\end{array}$ & & & CPR5, CPR6 & & & \\
\hline
\end{tabular}

\subsection{Ecosystem Integrity}

Here, we draw upon the definition and framework for ecosystem integrity proposed by Kay (1991), who argued that 'integrity' should be seen as an umbrella concept that integrates different characteristics of an ecosystem which, when taken together, describe an ecosystem's 
ability to maintain its organization, continue its process of self-organization and maintain its optimum operating point. This ability is the product of the functional role of species in ecosystem processes and emergent properties arising from their interactions, including the ability of an ecosystem to maintain its characteristic patterns and rates of process in response to the variability inherent in its climate regimes (De Leo and Levin 1997). Kay further argued that to be useful, the concept of ecosystem integrity must incorporate consideration of how changes in the ecosystem are valued by people and considered acceptable and desirable or otherwise. Kay's framework is based on the proposition that following change in the external environment, an ecosystem can respond in four ways. One response is for the system to continue to operate as before, even though its operations may be initially and temporally unsettled. A second response is for the system to operate at a different level (e.g. a commercially logged forest might be set back to a secondary early re-growth phase). A third response is for some new structures to emerge in the system to replace or augment existing structures (e.g. the forest is dominated by entirely new tree species). A fourth response can be catastrophic collapse of the system, and its replacement by an entirely different ecosystem type (e.g. a forest is replaced by a woody shrubland). For our purposes, the human component stressed by Kay is accounted for by understanding the change in the quantity and quality of ecosystem services arising from the four different system responses.

In this conceptualisation, the quality and quantity of ecosystem services is a function of the forest's ecosystem integrity. Land use activities can impact forest ecosystems in ways that change their structure and cause loss of biodiversity and species-specific functional traits. Reduced functionality from such impacts can include the loss of dominant trees species that control ecosystem dynamics; so-called "foundation species (Ellison et al. 2005). It is the biodiversity of primary forests, and the strong control the vegetation structure has on forest interior microclimates, that gives them their ecological resilience in the face of external stressors (Hooper et al. 2002; Holling 1973; Gunderson 2000), with resilient ecosystems having a complex structure and greater levels of biomass and functional diversity (Norris, Hobson, and Ibisch 2011).

A change in the kinds and mixes of land uses in a forest landscape will result in different levels of ecosystem integrity and changes in the type, quantity and quality of ecosystem services available. Converting from primary forest to plantation, for example, will generally result in a loss of regulating (e.g. climate, water, pollination, soil formation), cultural (e.g. aesthetic, spiritual and religious, cultural) and some provisioning services (e.g. food, genetic resources) in favour of a smaller number of provisioning services such as commodity production of woody fibre. Ultimately, a significant enough degradation in a forest's ecosystem integrity will result in it being unable to self-regenerate and maintain the ecosystem services that people and value.

Ecosystem integrity is most clearly reflected in the Ecosystem Approach principles, in particular EA5, EA6, EA10 and EA3. EA5 underpins the other three and highlights the need for ecosystem structure and function to be included within any approach to managing forest landscapes sustainably. EA6 adds the ecologically important idea of limits to human impacts if ecosystem functioning is to be maintained: while ecosystem services can be harnessed and utilised to benefit wellbeing, there are limits to their exploitation. EA10 recognises that these limits will result in trade-offs between conservation and use of ecosystems and the importance 
of maintaining biological diversity as vital for ecosystem integrity. Importantly, EA3 recognises the interconnectedness of ecosystems and the fact that management at any scale will involve drawing boundaries around ecosystems that are not necessarily reflected in nature (Duraiappah et al. 2014; Bodin and Tengö 2012).

Ostrom's principles and the LA principles are less explicit on the need to maintain ecosystem integrity, and assume landscape ecosystem integrity. The need for congruence between appropriation and provision rules and local conditions in Ostrom's principles (CPR2), as well as the focus on stability, imply a need for consistent and known resource provision, which in turn implies ecosystem integrity. Resilience (LA9) requires ecosystem integrity to be protected and maintained, as significant changes to ecosystem structure and function will make the landscape more vulnerable to change.

As Kay notes, consideration of how changes in the ecosystem are valued by people will affect changes to ecosystem integrity. Hence, knowledge and understanding of landscape ecosystem structures, functions, limits and services, and how activities impact upon them, are essential from a management perspective (Mori, Lertzman, and Gustafsson 2017; Musacchio 2013). Scientific knowledge will require monitoring and evaluation (LA1, LA8, EA3, EA5, EA6, EA9, CPR3), and long term decadal-plus time-scales management (EA7, EA9) because some ecosystem processes - such as canopy tree turnover - operate over longer time-scales than conventional management and monitoring. These challenges are exacerbated by the impacts arising from human-forced climate change, which may alter many ecosystems, rendering current knowledge based on previous observation and experience uncertain or irrelevant.

Values are also affected by other sources of knowledge (EA11) including traditional and local knowledge of the landscape's environmental, social, cultural and economic context (Dramstad and Fjellstad 2011; Mackey and Claudie 2015; Opdam et al. 2013). In forest landscapes, there is the risk of a loss of this local knowledge as forests are degraded or destroyed by extractive industries or people seek employment in cities and move away from traditional lifestyles, increasing the risk of loss of ecosystem integrity.

Responding to these changes therefore requires ongoing learning and adaptation (LA1, EA9) and the need to share these different types of knowledge. Ecosystem services and economic valuations of them (Albert et al. 2014; de Groot et al. 2010; Sitas et al. 2014) and adaptive management (Holling 1978; Messier et al. 2015) are important boundary work to share knowledge of ecosystem integrity within the landscape (Albert et al. 2014; Opdam et al. 2013), and provide the overlap and link to the planning pillar.

\subsection{Effective Planning}

This emphasis on knowledge and learning links directly to the second 'pillar', which is the need for effective planning. Planning has long been discussed as a process of turning knowledge into action (Campbell 2012; Friedmann 1987). Although planning can be used to mean a wide range of activities, planning theory provides a useful description of planning as a praxis, or moral public action, that seeks to bring together the technical that relates means to ends, the moral or ethical that considers how to live together equitably and fairly, and the 
utopian that provides a vision of 'the good life' (Friedmann 1987). In this definition, planning is a process that seeks to combine knowledge and values to create positive outcomes, which is fundamental to achieving many of the principles.

The first Ecosystem Approach principle highlights that "The objectives of management of land, water and living resources are a matter of societal choices". Choosing objectives that are fair, legitimate and have the desired outcomes is a planning process (Carvalho-Ribeiro, Lovett, and O'Riordan 2010). Planning processes can also help to identify the "appropriate balance between, and integration of, conservation and use of biological diversity" (EA10) (Bonsu, Dhubháin, and O'Connor 2017). Similarly, choosing rules over governing land use and ensuring benefits of natural resources are shared (CPR2) are land use planning activities (Marsh 2005; Metternicht 2018; Selman 2009). Economic analyses (EA4) of can help guide these planning decisions about balances and trade-offs (EA10) (Harrison 2017). Drawing boundaries in a landscape (CPR1, EA3), whether around resources or access, is a land use planning process that has to manage the mismatch of human and ecological systems.. Planning processes develop agreed goals and objectives (LA2, LA6, LA7, LA9, EA1, EA8, CPR2, CPR8), often making use of common concern entry points (LA2). Planning is a future-focused and iterative process that seeks to manage change, reflecting calls for adaptive and long term management (LA1, EA7, EA8, EA9, CPR2). An effective planning process also assigns responsibilities (LA6, LA7, EA2, CPR1, CPR2, CPR7, CPR8) and the resources required to carry out those responsibilities (LA10). Monitoring (LA1, LA8, EA3, EA5, EA6, EA9, CPR3), is also a planning challenge that is vital for linking action on the ground to both ecosystem integrity, planning and governance outcomes.

The principles recognise that landscapes and ecosystems function at multiple scales (LA3, EA7) and therefore management must take place at different levels (CPR8, EA7). EA2 requires that management should occur at the lowest possible level. However, it is important to ensure capacity and resources are allocated to those taking responsibility (LA10) and that there is coordination and integration across scales (LA3, LA6, LA7, EA3, EA7, EA10, CPR8). Reflecting this need for more integrated approaches and to respond to the challenges of globalisation, there is a growing literature on planning that seeks to combine the more multifunctional focus of regional strategic planning with more traditional local-level land use planning (Albrechts and Balducci 2013; Friedmann 2005). Landscape planning takes this approach, taking a more holistic and integrated view, treating ecological and cultural considerations more equally compared to the conventional social and economic focus of traditional land use planning (Dramstad and Fjellstad 2011; Matthews and Selman 2006; Selman 2005; Selman 2009). Landscape planning is also increasingly focused on participation and deliberation among stakeholders to achieve this integration between the biophysical and the socio-cultural (Selman 2004; Selman 2005; Selman 2009). These deliberative planning processes encourage social learning and co-production of knowledge (Friedmann 1981; Friedmann 2007), help stakeholders decide on a shared vision and create policies and objectives that are more likely to be accepted as legitimate (Forester 1999; Friedmann 2007; Legacy 2012; Whittemore 2015) and allow for the inclusion of values and culture within the decision-making in forest landscape systems (Jupiter 2017). Participation, however, is not a 
panacea; Arnstein emphasises that "participation without redistribution of power is an empty and frustrating process for the powerless" (Arnstein 1969, 219)) and participatory processes are vulnerable to being captured by powerful special interests (Cameron and Grant-Smith 2014).Planning is a moral practice that must take into account power relationships, and their resulting justice, equity and fairness issues within decisions over the allocation of land and resources (Cameron and Grant-Smith 2014; Forester 2007; Friedmann 2011), especially in landscapes that are highly contested, such as tropical forest landscapes subject to forest loss and unsustainable natural resource use and degradation. Co-produced planning processes seek to empower communities to plan and implement actions, as well as engage with formal State activities, to explicitly consider and challenge power and ensure more just and equitable outcomes (V. Watson 2014; Albrechts 2013). Importantly, these co-produced processes are of particular relevance for applying planning in the global south (Miraftab 2009).

Such co-production and deliberative processes can be slow and messy, and often require conflict resolution and ongoing engagement of a range of stakeholders (Forester 1999) and taking part in these may require the development of refinement of institutional rules, or norms of behaviour (Albrechts 2015) - hence strong governance is the final pillar.

\subsection{Governance}

Many of the principles relate to creating rules, involving multiple stakeholders, participation, rights and responsibilities and conflict resolution. These issues in turn relate to the governance system of the landscape. In this context, governance is the interactions between people, and the rules about their interactions with the landscape. The governance literature shows a clear relationship between effective environmental decision-making, meaningful participation and the utilisation of appropriate institutional arrangements, including capacity building, and particularly, the adequate provision of resources, financial or otherwise. Arnstein's "Ladder of Citizen Participation" still serves as one of the more cogent typological analyses of participation (Arnstein 1969). She considers participation a "categorical term for citizen power" (Arnstein 1969, 216), which represents a significant mechanism for social reform, as it redistributes power between the haves and the have-nots and enables the disadvantaged to share in the benefits of affluent society. It breaks down the nature of participation from the perspective of the citizen participant, and at one point in time. Hence, this typology provides a useful filter through which most decision-making processes could be screened.

Participation in the context of landscape systems is about citizen power and involvement in affecting decisions. Participation is key to Ostrom's principles of ensuring that those affected by the rules can participate in modifying the rules (CPR3) and developing a system, carried out by community members, for monitoring members' behaviour (CPR4). Similarly, the LA and EA principles emphasise participation in defining rules and monitoring (LA5, LA6, LA8, LA10, EA11), including the importance of capacity for participation (EA12). However, participation is not enough to create agreed rules. As Cadman (2012) notes, participation is a property of the governance structure but not its function. To achieve an output of agreed rules requires a process of discussion and consideration. Rational discourse is central to effective participation and deliberation in institutional governance systems (Habermas 1996). There 
have been some additions to this seminal concept in the last two decades, notably within governance theory and the understanding of the socio-political nature of participation and deliberation, as well as the structural and procedural aspects of effective and legitimate governance systems (Timothy Cadman 2011; Tim Cadman 2012; Kooiman 2000; Pierre and Peters 2000; Rhodes 1997). Mason's concept of environmental democracy is also relevant in the context of a landscape system, where both the socio-cultural and the ecological must be considered. Mason defines environmental democracy as "a participatory and ecologically rational form of collective decision-making" (Mason 1999, 1), which rests upon the view that communication and understanding between people is based upon, or at least allows for agreements that are based upon, convincing reasons rather than force or deception $(1999,8)$. Deliberation is essential to formulate agreed rights and responsibilities (LA6, LA7, EA2, CPR1, CPR2, CPR7, CPR8), create coordination and integration (LA3, LA6, LA7, EA3, EA7, EA10, CPR8) and ensure effective sanctions and conflict resolution processes (CPR5, CPR6).

Hence, creating strong governance requires meaningful participation and productive deliberation. Cadman (2012) provides a principles, criteria and analysis framework to guide creation and evaluation of governance processes and ensure strong governance. Further, this framework allows for the development of governance standards as a practical approach to developing participatory and deliberative governance. Recent work has demonstrated a process for developing governance standards for use for community-based forest management in Nepal (Maraseni et al. 2014). This governance standards approach can support more effective landscape planning, by ensuring participation and deliberation, and also ensure activities decided by the planning process are underpinned by strong governance.

\section{Three Pillar Framework for Integrating Forest Management Across the Landscape}

\subsection{The Three Pillar Framework}

We propose that the myriad of integrated landscape approaches to managing forest ecosystem services in place are all underpinned by three key overlapping pillars: (1) ecosystem integrity - defined by ecosystem processes, the functional roles of biodiversity and the resulting structures, functions and emergent properties; (2) effective planning - including shared learning, integration and justice; and (3) strong governance - based on meaningful participation and productive deliberation (Figure 3 ).

Building ecosystem structure and function into the landscape approach is critical to sustainable land use. But so too is recognising the economic and social imperatives that often drive local communities. Planning is essential for meeting the objectives of landscape management, particularly when there are multiple values and agendas in play. Robust governance structures and processes support effective landscape planning through participation and deliberation of stakeholders, and ensure activities decided by the planning process are properly implemented.

Each of the three pillars draws upon a substantial body of literature with approaches and tools to help implement and evaluate the framework. Similarly, the literature provides guidance on how the boundary concepts can be applied. The concept of ecosystem services, for example, 
makes clear the importance of ecosystem integrity and provides economic valuations that can assist in identifying synergies and trade-offs, while adaptive management provides a means to include ecosystem integrity and climate change into planning. Co-production and shared objectives will both support and be supported by effective planning and good governance.

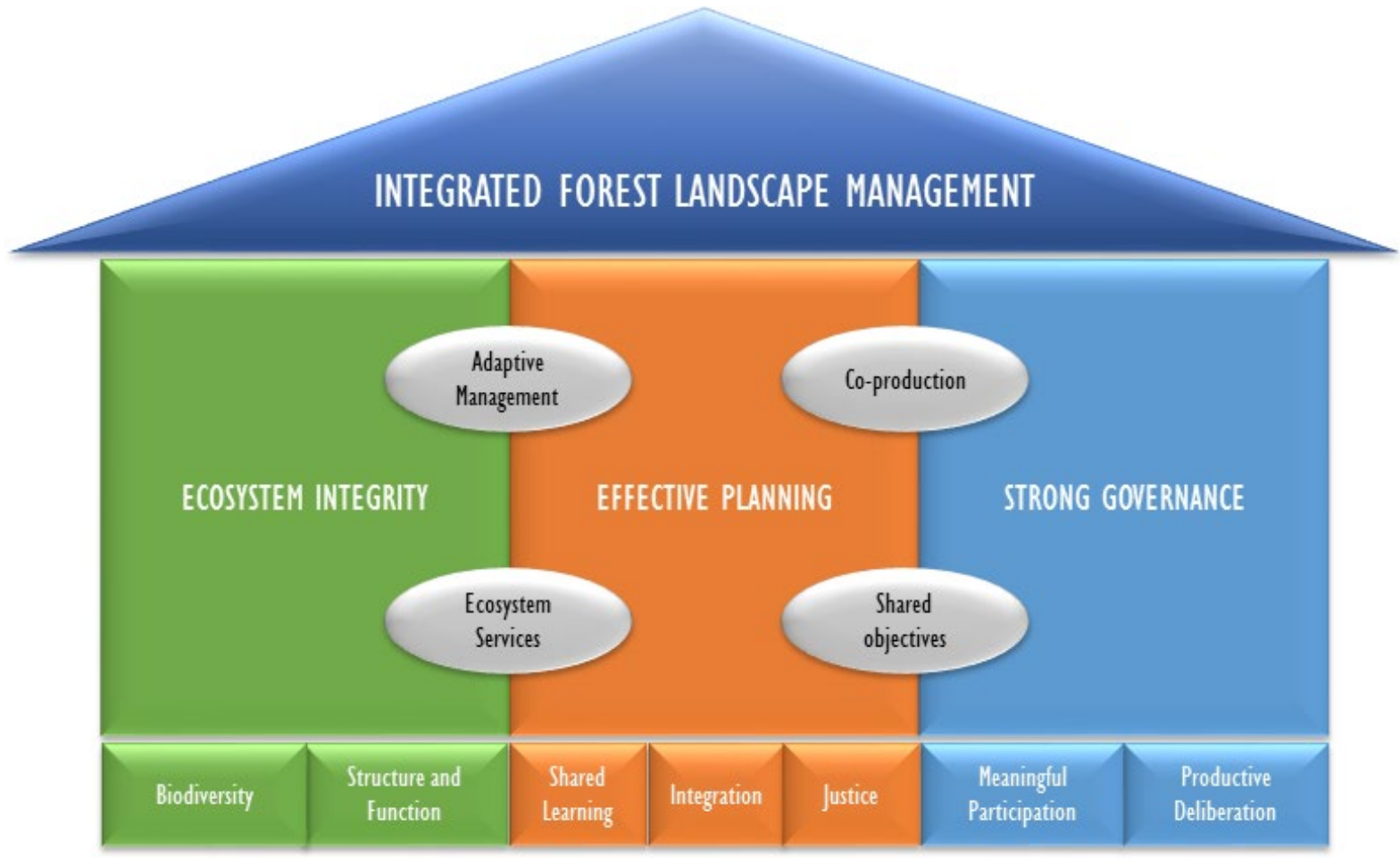

Figure 3: Three Pillar Framework for integrating forest management across the landscape. The three pillars and their foundations are derived from analysis of (1) the Ecosystem Approach - that emphasises ecosystem integrity, (2) the Landscape Approach - that emphasises effective planning, and (3) Common Pool Resource Management - that emphasises strong governance, in the context of forest landscapes. The principles that are represented here as the foundations of each pillar are discussed in Section 5. The pillars are strongly interlinked and the boundary concepts (adaptive management; ecosystem services; co-production; shared objectives) provide mechanisms that ensure their integration..

While many activities address more than one pillar (see Table 4), separating them in the framework helps to ensure all three are included, thus ensuring more holistic and integrated landscape management. Current approaches to forest management may only focus on one or two of these pillars: conventional conservation and ecosystem-based management approaches often focus on ecosystem integrity and planning (Watts et al. 2017), but have lacked a focus on governance and have led to top-down implementation (Agrawal, Chhatre, and Hardin 2008; Berkes 2010). CPR approaches tend to focus on institutions and some elements of planning, but do not explicitly consider ecosystem integrity, miss important ecosystem services and avoid equity and other planning considerations (Ostrom 1990; Agrawal 2014; Barnaud et al. 2018). A focus on only one or two pillars, risks missing crucial elements. Strong governance is about 'how' an integrated landscape approach is implemented, not the 'why' or the 'what' (Sampford, Cadman, and Maguire 2017, 23). Ecosystem integrity is about the 'why', providing the basis for understanding the impact of different land uses and management regimes on the quality and quantity of the ecosystem service stocks and flows in the landscape. Ignoring this pillar can lead to inadequate assessment of the trade-offs involved between competing land uses (Mace, 
Norris, and Fitter 2012; Seddon et al. 2020). Effective planning adds the 'what', defining and choosing the activities that manage the landscape and its ecosystem services by addressing the questions of 'what is our landscape', 'what are our objectives' and 'what is just'?

\subsection{Using the Three Pillar Framework: Outlook and Further Work}

Our approach advances integrated landscape management theory, specifically in the context of tropical primary forests, by building upon key components of widely-recognised landscape approaches. The three pillar framework advances theoretical understanding and articulates a conceptual framework that can provide a solid foundation for supporting real world applications. The framework proposes that integrated landscape management of tropical primary forest landscapes requires tools, processes and practices that ensure all three pillars are explicitly addressed. It also provides broad principles that can underpin effective integrated landscape approaches for tropical primary forests.

We recognise that achieving the 'ideals' of all three elements will be resource intensive and is unlikely to be met in all contexts, however the significant overlaps and reinforcing elements of these three pillars can be harnessed to rationalise effort. For example, ensuring strong participatory and collaborative governance will support effective planning, which in turn will support the inclusion of ecosystem integrity into decision-making, through expert and other knowledge.

Further work is needed to operationalise the three pillar framework. The framework provides high level principles for the development of criteria, indicators and verifiers required for fieldbased application. Further work is also needed to empirically test the framework, link it to planning tools, and maximise synergies. Future work can also test how other principles identified in the literature are covered by the framework, for example how co-productive planning will help address ambiguity (Brugnach and Ingram 2012).

Finally, this framework has been developed in the context of tropical forest landscapes. This focus reflects the wide and varied use of the landscape approach and ecosystem approach in these contexts, which stems in part from the global focus on preventing deforestation in developing countries; industrialised countries tend to see deforestation as a developing country problem (NYDF Assessment Partners 2019), despite high deforestation rates across the globe. However, our framework may be relevant to boreal and temperate forests landscape management in a developed country context, given growing and competing demands on forest resources (FAO 2020). We will seek to demonstrate this more general applicability in future work. Furthermore, the framework is potentially applicable to non-forest landscapes facing similar competing land use pressures. We would encourage specialists in other landscape contexts to further analyse, apply and critique the framework presented here.

\section{Conclusion}

This paper proposes a novel three pillar framework for integrating forest management across a landscape. The framework was developed by identifying key theoretical components of integrated landscape approaches and re-analysing and synthesising existing common sets of principles for implementation of them in the context of tropical forest landscapes. The 
framework proposes that ecosystem integrity, effective planning and strong governance are fundamental pillars of forest landscape management, and all must be addressed for effective and sustainable forest landscape management. The framework can be used to help choose and develop appropriate tools to support an integrated landscape approach to forest management, including appropriate principles, criteria and indicators for monitoring and assessment.

Integrating social, environmental and economic values through the framework proposed here could help avoid the fragmentation of ecosystems, stakeholders, policy, and practice currently evident in forest landscapes, and could be widely applicable to guiding integrated landscape approaches more generally.

\section{Acknowledgements}

The research reported here was supported by a charitable organization which neither seeks nor permits publicity for its efforts. The trust has had no influence on the design, analysis, interpretation and documentation of this research. The authors would like to thank the three referees whose feedback greatly improved the paper. 


\section{References}

Achard, Frédéric, René Beuchle, Philippe Mayaux, Hans-Jürgen Stibig, Catherine Bodart, Andreas Brink, Silvia Carboni, et al. 2014. "Determination of Tropical Deforestation Rates and Related Carbon Losses from 1990 to 2010." Global Change Biology 20 (8): 2540-2554. doi:10.1111/gcb.12605.

Adger, W. Neil, Katrina Brown, Jenny Fairbrass, Andrew Jordan, Jouni Paavola, Sergio Rosendo, and Gill Seyfang. 2003. "Governance for Sustainability: Towards a 'thick' Analysis of Environmental Decisionmaking." Environment and Planning A 35 (6): 1095-1110. doi:10.1068/a35289.

Agrawal, Arun. 2014. "Studying the Commons, Governing Common-Pool Resource Outcomes: Some Concluding Thoughts." Environmental Science \& Policy, Interrogating The Commons, 36 (February): 86-91. doi:10.1016/j.envsci.2013.08.012.

Agrawal, Arun, Ashwini Chhatre, and Rebecca Hardin. 2008. "Changing Governance of the World's Forests.” Science 320 (5882): 1460-1462. doi:10.1126/science.1155369.

Albert, Christian, James Aronson, Christine Fürst, and Paul Opdam. 2014. "Integrating Ecosystem Services in Landscape Planning: Requirements, Approaches, and Impacts." Landscape Ecology 29 (8): 1277-1285. doi:10.1007/s10980-014-0085-0.

Albrechts, Louis. 2013. "Reframing Strategic Spatial Planning by Using a Coproduction Perspective." Planning Theory 12 (1). SAGE Publications: 46-63. doi:10.1177/1473095212452722.

Albrechts, Louis. 2015. "Ingredients for a More Radical Strategic Spatial Planning." Environment and Planning B: Planning and Design 42 (3). SAGE Publications Ltd STM: 510-525. doi:10.1068/b130104p.

Albrechts, Louis, and Alessandro Balducci. 2013. "Practicing Strategic Planning: In Search of Critical Features to Explain the Strategic Character of Plans." DisP - The Planning Review 49 (3). Routledge: 16-27. doi:10.1080/02513625.2013.859001.

Angelstam, Per, Marine Elbakidze, Robert Axelsson, Alexander Khoroshev, Bas Pedroli, Maria Tysiachniouk, and Evgeny Zabubenin. 2019. "Model Forests in Russia as Landscape Approach: Demonstration Projects or Initiatives for Learning towards Sustainable Forest Management?" Forest Policy and Economics 101 (April): 96-110. doi:10.1016/j.forpol.2019.01.005.

Arnstein, Sherry. 1969. “A Ladder Of Citizen Participation." Journal of the American Planning Association 35 (4): 216-224. doi:10.1080/01944366908977225.

Arts, Bas, Marleen Buizer, Lumina Horlings, Verina Ingram, Cora van Oosten, and Paul Opdam. 2017. "Landscape Approaches: A State-of-the-Art Review." Annual Review of Environment and Resources 42 (1): 439-463. doi:10.1146/annurev-environ102016-060932.

Baldwin, Robert F., Stephen C. Trombulak, Paul B. Leonard, Reed F. Noss, Jodi A. Hilty, Hugh P. Possingham, Lynn Scarlett, and Mark G. Anderson. 2018. "The Future of Landscape Conservation.” BioScience 68 (2): 60-63. doi:10.1093/biosci/bix 142.

Barlow, J., T. A. Gardner, I. S. Araujo, T. C. Avila-Pires, A. B. Bonaldo, J. E. Costa, M. C. Esposito, et al. 2007. "Quantifying the Biodiversity Value of Tropical Primary, Secondary, and Plantation Forests." Proceedings of the National Academy of Sciences 104 (47): 18555-18560. doi:10.1073/pnas.0703333104.

Barnaud, Cecile, Esteve Corbera, Roldan Muradian, Nicolas Salliou, Clélia Sirami, Aude Vialatte, Jean-Philippe Choisis, et al. 2018. "Ecosystem Services, Social Interdependencies, and Collective Action: A Conceptual Framework." Ecology and Society 23 (1). Resilience Alliance Inc.: 15. doi:10.5751/ES-09848-230115.

Bartuszevige, Anne M., Kyle Taylor, Alex Daniels, and Michael F. Carter. 2016. "Landscape Design: Integrating Ecological, Social, and Economic Considerations into 
Conservation Planning." Wildlife Society Bulletin 40 (3): 411-422.

doi:10.1002/wsb.683.

Bebbington, Anthony J., Denise Humphreys Bebbington, Laura Aileen Sauls, John Rogan, Sumali Agrawal, César Gamboa, Aviva Imhof, et al. 2018. "Resource Extraction and Infrastructure Threaten Forest Cover and Community Rights." Proceedings of the National Academy of Sciences 115 (52): 13164-13173. doi:10.1073/pnas.1812505115.

Bell, Simon, and Dean Apostol. 2007. Designing Sustainable Forest Landscapes. London and New York: Taylor \& Francis.

Berkes, Fikret. 2009. "Evolution of Co-Management: Role of Knowledge Generation, Bridging Organizations and Social Learning." Journal of Environmental Management 90 (5): 1692-1702. doi:10.1016/j.jenvman.2008.12.001.

Berkes, Fikret. 2010. "Devolution of Environment and Resources Governance: Trends and Future." Environmental Conservation 37 (4): 489-500. doi:10.1017/S037689291000072X.

Beunen, Raoul, and Paul Opdam. 2011. "When Landscape Planning Becomes Landscape Governance, What Happens to the Science?" Landscape and Urban Planning, Landscape and Urban Planning at 100, 100 (4): 324-326. doi:10.1016/j.landurbplan.2011.01.018.

Bodin, Örjan, and Maria Tengö. 2012. "Disentangling Intangible Social-Ecological Systems." Global Environmental Change, Adding Insult to Injury: Climate Change, Social Stratification, and the Inequities of Intervention, 22 (2): 430-439. doi:10.1016/j.gloenvcha.2012.01.005.

Bonsu, Nana O., Áine Ní Dhubháin, and Deirdre O’Connor. 2017. "Evaluating the Use of an Integrated Forest Land-Use Planning Approach in Addressing Forest Ecosystem Services Conflicting Demands: Experience within an Irish Forest Landscape." Futures 86 (February): 1-17. doi:10.1016/j.futures.2016.08.004.

Brugnach, Marcela, Art Dewulf, Claudia Pahl-Wostl, and Tharsi Taillieu. 2008. "Toward a Relational Concept of Uncertainty: About Knowing Too Little, Knowing Too Differently, and Accepting Not to Know." Ecology and Society 13 (2): 30. doi:10.5751/ES-02616-130230.

Brugnach, Marcela, and H. Ingram. 2012. "Ambiguity: The Challenge of Knowing and Deciding Together.” Environmental Science \& Policy 15 (1): 60-71. doi:10.1016/j.envsci.2011.10.005.

Brunckhorst, David J. 2013. Bioregional Planning: Resource Management Beyond the New Millennium. London and New York: Routledge.

Buckwell, Andrew, Dan Ware, Christopher Fleming, James C. R. Smart, Brendan Mackey, Johanna Nalau, and Allan Dan. 2020. "Social Benefit Cost Analysis of EcosystemBased Climate Change Adaptations: A Community-Level Case Study in Tanna Island, Vanuatu." Climate and Development 12 (6): 495-510. doi:10.1080/17565529.2019.1642179.

Buizer, Marleen, Bas Arts, and Judith Westerink. 2016. "Landscape Governance as Policy Integration 'from below': A Case of Displaced and Contained Political Conflict in the Netherlands." Environment and Planning C: Government and Policy 34 (3): 448-462. doi:10.1177/0263774X15614725.

Bush, Glenn K, Melaine Kermarc, and Joseph Zambo. 2015. Free Prior and Informed Consent in the DRC; Key Strategic Considerations to Move the Policy Process Forward. Policy Discussion 1. Woods Hole, MA: Woods Hole Research Center. http://projetequateur.org/wp-content/uploads/2016/03/DRC-_CLIP_policy-brief_No1.pdf. 
Cadman, Tim. 2012. "Evaluating the Quality and Legitimacy of Global Governance: A Theoretical and Analytical Approach." The International Journal of Social Quality 2 (1): 4-23.

Cadman, Timothy. 2011. Quality and Legitimacy of Global Governance. London: Palgrave Macmillan UK. doi:10.1057/9780230306462.

Cameron, Jenny, and Deanna Grant-Smith. 2014. "Putting People in Planning: Participatory Planning, Inclusion and Power.” In Australian Environmental Planning: Challenges and Future Prospects, edited by Jason Byrne, Jago Dodson, and Neil Sipe, 197-205. London: Routledge.

Campbell, Heather. 2012. "Planning to Change the World: Between Knowledge and Action Lies Synthesis." Journal of Planning Education and Research 32 (2): 135-146. doi:10.1177/0739456X11436347.

Carvalho-Ribeiro, S. M., A. Lovett, and T. O'Riordan. 2010. "Multifunctional Forest Management in Northern Portugal: Moving from Scenarios to Governance for Sustainable Development." Land Use Policy 27 (4): 1111-1122. doi:10.1016/j.landusepol.2010.02.008.

Chazdon, Robin L., Pedro H. S. Brancalion, Lars Laestadius, Aoife Bennett-Curry, Kathleen Buckingham, Chetan Kumar, Julian Moll-Rocek, Ima Célia Guimarães Vieira, and Sarah Jane Wilson. 2016. "When Is a Forest a Forest? Forest Concepts and Definitions in the Era of Forest and Landscape Restoration." Ambio 45 (5): 538-550. doi:10.1007/s13280-016-0772-y.

Convention on Biological Diversity. 2007. "Ecosystem Approach -Principles." https://www.cbd.int/ecosystem/principles.shtml.

Cox, Michael, Gwen Arnold, and Sergio Villamayor Tomás. 2010. "A Review of Design Principles for Community-Based Natural Resource Management." Ecology and Society 15 (4): 38. doi:10.5751/ES-03704-150438.

Curtin, C. G., and G. M. Tabor. 2016. "Large Landscape Conservation: Addressing the Realities of Scale and Complexity." In Reference Module in Earth Systems and Environmental Sciences. Elsevier. doi:10.1016/B978-0-12-409548-9.09210-1.

Curtis, Philip G., Christy M. Slay, Nancy L. Harris, Alexandra Tyukavina, and Matthew C. Hansen. 2018. "Classifying Drivers of Global Forest Loss." Science 361 (6407): 1108-1111. doi:10.1126/science.aau3445.

de Groot, Rudolf S., R. Alkemade, L. Braat, L. Hein, and L. Willemen. 2010. "Challenges in Integrating the Concept of Ecosystem Services and Values in Landscape Planning, Management and Decision Making." Ecological Complexity, Ecosystem Services Bridging Ecology, Economy and Social Sciences, 7 (3): 260-272. doi:10.1016/j.ecocom.2009.10.006.

de Groot, Rudolf S., Matthew A. Wilson, and Roelof M J Boumans. 2002. "A Typology for the Classification, Description and Valuation of Ecosystem Functions, Goods and Services." Ecological Economics 41 (3): 393-408. doi:10.1016/S09218009(02)00089-7.

De Leo, Giulio A., and Simon Levin. 1997. "The Multifaceted Aspects of Ecosystem Integrity.” Conservation Ecology 1 (1). Resilience Alliance Inc.: 3. doi:10.5751/ES00022- Q8 010103.

Dellasala, Dominick A, Cyril F Kormos, Heather Keith, Brendan Mackey, Virginia Young, Brendan Rogers, and Russell A Mittermeier. 2020. "Primary Forests Are Undervalued in the Climate Emergency." BioScience 70 (6): 445-445. doi:10.1093/biosci/biaa030.

Dernier, Louisa, Sarah Scherr, Seth Shames, Paul Chatterton, Lee Hovani, and Nienke Stam. 2015. The Little Sustanable Landscapes Book. Oxford: Global Coanopy Project. 
Diaz, Nancy M. 1992. Forest Landscape Analysis and Design: A Process for Developing and Implementing Land Management Objectives for Landscape Patterns. USDA Forest Service, Pacific Northwest Region.

Dirzo, Rodolfo, and Peter H. Raven. 2003. "Global State of Biodiversity and Loss." Annual Review of Environment and Resources 28 (1): 137-167. doi:10.1146/annurev.energy.28.050302.105532.

Dramstad, Wenche E., and Wendy J. Fjellstad. 2011. "Landscapes: Bridging the Gaps between Science, Policy and People." Landscape and Urban Planning, Landscape and Urban Planning at 100, 100 (4): 330-332. doi:10.1016/j.landurbplan.2011.02.003.

Dubiński, Józef. 2013. "Sustainable Development of Mining Mineral Resources." Journal of Sustainable Mining 12 (1): 1-6. doi:10.7424/jsm130102.

Duraiappah, Anantha Kumar, Stanley Tanyi Asah, Eduardo S Brondizio, Nicolas Kosoy, Patrick J O'Farrell, Anne-Helene Prieur-Richard, Suneetha M Subramanian, and Kazuhiko Takeuchi. 2014. "Managing the Mismatches to Provide Ecosystem Services for Human Well-Being: A Conceptual Framework for Understanding the New Commons." Current Opinion in Environmental Sustainability, Environmental change issues, 7 (April): 94-100. doi:10.1016/j.cosust.2013.11.031.

Ehrlich, Paul R., and Harold A. Mooney. 1983. "Extinction, Substitution, and Ecosystem Services.” BioScience 33 (4): 248-254. doi:10.2307/1309037.

Ellis, Edward A., and Luciana Porter-Bolland. 2008. "Is Community-Based Forest Management More Effective than Protected Areas?: A Comparison of Land Use/Land Cover Change in Two Neighboring Study Areas of the Central Yucatan Peninsula, Mexico." Forest Ecology and Management 256 (11): 1971-1983. doi:10.1016/j.foreco.2008.07.036.

Ellison, Aaron M., Michael S. Bank, Barton D. Clinton, Elizabeth A. Colburn, Katherine Elliott, Chelcy R. Ford, David R. Foster, et al. 2005. "Loss of Foundation Species: Consequences for the Structure and Dynamics of Forested Ecosystems." Frontiers in Ecology and the Environment 3 (9): 479-486. doi:10.1890/15409295(2005)003[0479:LOFSCF]2.0.CO;2.

Erbaugh, James, and Arun Agrawal. 2017. "Clarifying the Landscape Approach: A Letter to the Editor on 'Integrated Landscape Approaches to Managing Social and Environmental Issues in the Tropics." Global Change Biology, n/a-n/a. doi:10.1111/gcb.13788.

Erbaugh, James, and Johan Oldekop. 2018. "Forest Landscape Restoration for Livelihoods and Well-Being." Current Opinion in Environmental Sustainability, Environmental change issues 2018, 32 (June): 76-83. doi:10.1016/j.cosust.2018.05.007.

FAO. 2015. FRA 2015. Terms and Definitions. Forest Resources Assessment Working Paper 180. Working Paper 180. Rome: FAO. http://www.fao.org/3/ap862e/ap862e00.pdf.

FAO. 2020. Global Forest Resources Assessment 2020. Rome: FAO. doi:10.4060/ca8753en. FAO and UNEP. 2020. The State of the World's Forests 2020. Forests, Biodiversity and People. Rome: FAO and UNEP. doi:10.4060/ca8642en.

Farran, Sue. 2016. "Timber Extraction in Solomon Islands: Too Much, Too Fast; Too Little, Too Late." In Natural Resource Extraction and Indigenous Livelihoods, edited by Emma Gilberthorpe and Gavin Hilson. Abingdon, UK: Routledge. doi:10.4324/9781315597546-13.

Filer, Colin. 2012. "Why Green Grabs Don't Work in Papua New Guinea." The Journal of Peasant Studies 39 (2): 599-617. doi:10.1080/03066150.2012.665891.

Folke, Carl, Stephen R Carpenter, Brian Walker, Marten Scheffer, and Terry Chapin. 2010. "Resilience Thinking: Integrating Resilience, Adaptability and Transformability." Ecology and Society 15 (4): 20. 
Forester, John. 1999. The Deliberative Practitioner: Encouraging Participatory Planning Processes. Cambridge, MA: MIT Press.

Forester, John. 2007. "Planning in the Face of Power." In Planning History and Methodology, edited by Michael Wegener, Kenneth Button, and Peter Nijkamp, 6780. Cheltenham, UK: Edward Elgar.

Franklin, Jerry F. 1993. "Preserving Biodiversity: Species, Ecosystems, or Landscapes?" Ecological Applications 3 (2): 202-205.

Freeman, Olivia E., Lalisa A. Duguma, and Peter A. Minang. 2015. "Operationalizing the Integrated Landscape Approach in Practice.” Ecology and Society 20 (1): 24. doi:10.5751/ES-07175-200124.

Friedmann, John. 1981. Planning as Social Learning. 343. Berkeley, CA: Institute of Urban and Regional Development.

Friedmann, John. 1987. Planning in the Public Domain: From Knowledge to Action. Princeton, NJ: Princeton University Press.

Friedmann, John. 2005. "Globalization and the Emerging Culture of Planning." Progress in Planning 64 (3): 183-234. doi:10.1016/j.progress.2005.05.001.

Friedmann, John. 2007. "Planning in the Public Domain: Discourse and Praxis." In Planning History and Methodology, edited by Michael Wegener, Kenneth Button, and Peter Nijkamp, 67-80. Cheltenham, UK: Edward Elgar.

Friedmann, John. 2011. Insurgencies: Essays in Planning Theory. Abingdon, UK: Routledge.

Gardner, Roy, Elinor Ostrom, and James M. Walker. 1990. "The Nature of Common-Pool Resource Problems." Rationality and Society 2 (3): 335-358. doi:10.1177/1043463190002003005.

Görg, Christoph. 2007. 'Landscape Governance: The 'Politics of Scale' and the 'Natural' Conditions of Places." Geoforum, Pro-Poor Water? The Privatisation and Global Poverty Debate, 38 (5): 954-966. doi:10.1016/j.geoforum.2007.01.004.

Gunderson, Lance H. 2000. "Ecological Resilience-In Theory and Application." Annual Review of Ecology and Systematics 31 (1): 425-439. doi:10.1146/annurev.ecolsys.31.1.425.

Habermas, Jurgen. 1996. Between Facts and Norms: Contributions to a Discourse Theory of Law and Democracy. Translated by William Rehg. Boston, MA: MIT Press.

Hansen, M. C., P. V. Potapov, R. Moore, M. Hancher, S. A. Turubanova, A. Tyukavina, D. Thau, et al. 2013. "High-Resolution Global Maps of 21st-Century Forest Cover Change." Science 342 (6160). American Association for the Advancement of Science: 850-853. doi:10.1126/science.1244693.

Harrison, A. J. 2017. Economics and Land Use Planning. Routledge. doi:10.4324/9781315112022.

Holling, C S. 1973. "Resilience and Stability of Ecological Systems." Annual Review of Ecology and Systematics 4 (1): 1-23. doi:10.1146/annurev.es.04.110173.000245.

Holling, C. S. 1978. Adaptive Environmental Assessment and Management. London: John Wiley and Sons.

Hooper, D. U., M. Solan, A. Symstad, S. Diaz, M. O. Gessner, N. Buchmann, V. Degrange, et al. 2002. "Species Diversity, Functional Diversity, and Ecosystem Functioning." In Biodiversity and Ecosystem Functioning: Synthesis and Perspectives. Oxford, New York: Oxford University Press.

Ianni, Elena, and Davide Geneletti. 2010. “Applying the Ecosystem Approach to Select Priority Areas for Forest Landscape Restoration in the Yungas, Northwestern Argentina." Environmental Management 46 (5): 748-760. doi:10.1007/s00267-0109553-8. 
IPCC. 2015. Climate Change 2014: Synthesis Report. Geneva, Switzerland: Intergovernmental Panel on Climate Change.

IUCN, and WRI. 2016. A Guide to the Restoration Opportunities Assessment Methodology (ROAM): Assessing Forest Landscape Restoration Opportunities at the National or Sub-National Level. Working Paper (Road-test edition). Gland, Switzerland: IUCN. https://www.iucn.org/theme/forests/our-work/forest-landscape-restoration/restorationopportunities-assessment-methodology-roam.

Jupiter, Stacy. 2017. "Culture, Kastom and Conservation in Melanesia: What Happens When Worldviews Collide?" Pacific Conservation Biology 23 (2): 139-145. doi:10.1071/PC16031.

Katovai, Eric, Will Edwards, and William F. Laurance. 2015. "Dynamics of Logging in Solomon Islands: The Need for Restoration and Conservation Alternatives." Tropical Conservation Science 8 (3): 718-731. doi:10.1177/194008291500800309.

Kay, James J. 1991. "A Nonequilibrium Thermodynamic Framework for Discussing Ecosystem Integrity.” Environmental Management 15 (4): 483-495. doi:10.1007/BF02394739.

Kim, Do-Hyung, Joseph O. Sexton, and John R. Townshend. 2015. "Accelerated Deforestation in the Humid Tropics from the 1990s to the 2000s." Geophysical Research Letters 42 (9): 3495-3501. doi:10.1002/2014GL062777.

Kooiman, J. 2000. "Societal Governance: Levels, Models, and Orders of Social-Political Interaction." In Debating Governance: Authority, Steering and Democracy, edited by Jon Pierre, 138-166. Oxford: Oxford University Press.

Laurance, William F., Jeffrey A. Sayer, and Kenneth G. Cassman. 2014. "Agricultural Expansion and Its Impacts on Tropical Nature." Trends in Ecology \& Evolution 29 (2): 107-116. doi:10.1016/j.tree.2013.12.001.

Leblois, Antoine, Olivier Damette, and Julien Wolfersberger. 2017. "What Has Driven Deforestation in Developing Countries Since the 2000s? Evidence from New RemoteSensing Data." World Development 92 (April): 82-102. doi:10.1016/j.worlddev.2016.11.012.

Legacy, Crystal. 2012. "Achieving Legitimacy Through Deliberative Plan-Making Processes - Lessons for Metropolitan Strategic Planning." Planning Theory \& Practice 13 (1): 71-87. doi:10.1080/14649357.2012.649947.

Lindenmayer, David B., and Saul A. Cunningham. 2013. "Six Principles for Managing Forests as Ecologically Sustainable Ecosystems." Landscape Ecology 28 (6): 10991110. doi:10.1007/s10980-012-9720-9.

Lindenmayer, David B., and Richard J. Hobbs. 2008. Managing and Designing Landscapes for Conservation: Moving from Perspectives to Principles. Carlton, VIC, Australia: Blackwell Publishing.

Lockwood, Michael, Julie Davidson, Allan Curtis, Elaine Stratford, and Rod Griffith. 2010. “Governance Principles for Natural Resource Management." Society \& Natural Resources 23 (10): 986-1001. doi:10.1080/08941920802178214.

Mace, Georgina M., Ken Norris, and Alastair H. Fitter. 2012. "Biodiversity and Ecosystem Services: A Multilayered Relationship." Trends in Ecology \& Evolution 27 (1): 1926. doi:10.1016/j.tree.2011.08.006.

Mackey, Brendan, and David Claudie. 2015. "Points of Contact: Integrating Traditional and Scientific Knowledge for Biocultural Conservation." Environmental Ethics 37 (3): 341-357. doi:10.5840/enviroethics201537332.

Mackey, Brendan, Dominick A. DellaSala, Cyril Kormos, David Lindenmayer, Noelle Kumpel, Barbara Zimmerman, Sonia Hugh, et al. 2015. "Policy Options for the 
World's Primary Forests in Multilateral Environmental Agreements." Conservation Letters 8 (2): 139-147. doi:10.1111/conl.12120.

Mackey, Brendan, Cyril F. Kormos, Heather Keith, William R. Moomaw, Richard A.

Houghton, Russell A. Mittermeier, David Hole, and Sonia Hugh. 2020.

"Understanding the Importance of Primary Tropical Forest Protection as a Mitigation Strategy." Mitigation and Adaptation Strategies for Global Change, March. doi:10.1007/s11027-019-09891-4.

Mackey, Brendan, Johanna Nalau, Oz Sahin, Christopher Fleming, James C. R. Smart, Rod Connolly, Willow Hallgren, and Andrew J. Buckwell. 2017. Vanuatu Ecosystem and Socio-Economic Resilience Analysis and Mapping (ESRAM). Apia, Samoa:

Secretariat for the Pacific Regional Environment Program (SPREP).

https://pacificdata.org/data/dataset/ecosystem-and-socio-economic-resilienceanalysis-and-mapping-vanuatu132ddf1c-21a5-4412-8a60-6dd.

Maraseni, T. N., P. R. Neupane, F. Lopez-Casero, and Tim Cadman. 2014. "An Assessment of the Impacts of the REDD+ Pilot Project on Community Forests User Groups (CFUGs) and Their Community Forests in Nepal." Journal of Environmental Management 136 (April): 37-46. doi:10.1016/j.jenvman.2014.01.011.

Marsh, William. 2005. Landscape Planning: Environmental Applications. 4th ed. Hoboken, NJ: John Wiley \& Sons.

Martin, Tara G., and James E. M. Watson. 2016. "Intact Ecosystems Provide Best Defence against Climate Change." Nature Climate Change 6 (January): 122-124. doi:10.1038/nclimate2918.

Martín-López, Berta, María R. Felipe-Lucia, Elena M. Bennett, Albert Norström, Garry Peterson, Tobias Plieninger, Christina C. Hicks, et al. 2019. "A Novel Telecoupling Framework to Assess Social Relations across Spatial Scales for Ecosystem Services Research.” Journal of Environmental Management 241 (July): 251-263. doi:10.1016/j.jenvman.2019.04.029.

Mason, Michael. 1999. Environmental Democracy. London: Earthscan.

Matthews, Robin, and Paul Selman. 2006. "Landscape as a Focus for Integrating Human and Environmental Processes.” Journal of Agricultural Economics 57 (2): 199-212.

McCall, Michael K. 2016. "Beyond 'Landscape' in REDD+: The Imperative for 'Territory." World Development 85 (September): 58-72. doi:10.1016/j.worlddev.2016.05.001.

McNamara, Eva A., Melaine Kermarc, Joseph Zambo Mandea, and Glenn Bush. 2018. "Tertiary Education Knowledge and Standards in Sustainable Development: A Crisis for the Democratic Republic of the Congo." In Climate Literacy and Innovations in Climate Change Education: Distance Learning for Sustainable Development, edited by Ulisses M. Azeiteiro, Walter Leal Filho, and Luísa Aires, 85-108. Climate Change Management. Cham: Springer International Publishing. doi:10.1007/978-3-31970199-8_6.

Megevand, Carole, Aline Mosnier, Joël Hourticq, Klas Sanders, Nina Doetinchem, and Charlotte Streck. 2013. Deforestation Trends in the Congo Basin: Reconciling Economic Growth and Forest Protection. Washington, D.C.: The World Bank. doi:10.1596/978-0-8213-9742-8.

Menz, Myles H. M., Kingsley W. Dixon, and Richard J. Hobbs. 2013. "Hurdles and Opportunities for Landscape-Scale Restoration.” Science 339 (6119): 526-527. doi:10.1126/science.1228334.

Messier, C., K. Puettmann, R. Chazdon, K. P. Andersson, V. A. Angers, L. Brotons, E. Filotas, R. Tittler, L. Parrott, and S. A. Levin. 2015. "From Management to Stewardship: Viewing Forests As Complex Adaptive Systems in an Uncertain World." Conservation Letters 8 (5): 368-377. doi:10.1111/conl.12156. 
Metternicht, Graciela. 2018. Land Use and Spatial Planning : Enabling Sustainable Management of Land Resources. SpringerBriefs in Earth Sciences.

Cham,Switzerland: Springer International Publishing.

//www.springer.com/gp/book/9783319718606.

Millennium Ecosystem Assessment Board. 2005. Ecosystems and Human Wellbeing.

Washington, D.C.: Island Press. http://www.millenniumassessment.org.

Miraftab, Faranak. 2009. "Insurgent Planning: Situating Radical Planning in the Global South.” Planning Theory 8 (1). SAGE Publications: 32-50. doi:10.1177/1473095208099297.

Mladenoff, David J., Mark A. White, Thomas R. Crow, and John Pastor. 1994. “Applying Principles of Landscape Design and Management to Integrate Old-Growth Forest Enhancement and Commodity Use." Conservation Biology 8 (3): 752-762. doi:10.1046/j.1523-1739.1994.08030752.x.

Moomaw, William R., Susan A. Masino, and Edward K. Faison. 2019. "Intact Forests in the United States: Proforestation Mitigates Climate Change and Serves the Greatest Good." Frontiers in Forests and Global Change 2: 27. doi:10.3389/ffgc.2019.00027.

Moreno-Mateos, David, Edward B. Barbier, Peter C. Jones, Holly P. Jones, James Aronson, José A. López-López, Michelle L. McCrackin, Paula Meli, Daniel Montoya, and José M. Rey Benayas. 2017. "Anthropogenic Ecosystem Disturbance and the Recovery Debt." Nature Communications 8 (1): 14163. doi:10.1038/ncomms14163.

Mori, Akira S., Kenneth P. Lertzman, and Lena Gustafsson. 2017. "Biodiversity and Ecosystem Services in Forest Ecosystems: A Research Agenda for Applied Forest Ecology." Edited by Marc Cadotte. Journal of Applied Ecology 54 (1): 12-27. doi:10.1111/1365-2664.12669.

Musacchio, Laura R. 2013. "Key Concepts and Research Priorities for Landscape Sustainability." Landscape Ecology 28 (6): 995-998. doi:10.1007/s10980-013-99096.

Nadrowski, Karin, Christian Wirth, and Michael Scherer-Lorenzen. 2010. "Is Forest Diversity Driving Ecosystem Function and Service?" Current Opinion in Environmental Sustainability 2 (1-2): 75-79. doi:10.1016/j.cosust.2010.02.003.

Nagendra, Harini, and Elinor Ostrom. 2012. "Polycentric Governance of Multifunctional Forested Landscapes." International Journal of the Commons 6 (2): 104. doi:10.18352/ijc.321.

Nelson, Paul N., Jennifer Gabriel, Colin Filer, Murom Banabas, Jeffrey A. Sayer, George N. Curry, Gina Koczberski, and Oscar Venter. 2014. "Oil Palm and Deforestation in Papua New Guinea.” Conservation Letters 7 (3): 188-195. doi:10.1111/conl.12058.

Nielsen, Tobias Dan. 2016. "From REDD+ Forests to Green Landscapes? Analyzing the Emerging Integrated Landscape Approach Discourse in the UNFCCC." Forest Policy and Economics 73 (December): 177-184. doi:10.1016/j.forpol.2016.09.006.

Norris, Catherine, Peter Hobson, and Pierre L. Ibisch. 2011. "Microclimate and Vegetation Function as Indicators of Forest Thermodynamic Efficiency." Journal of Applied Ecology 49 (3): 562-570. doi:10.1111/j.1365-2664.2011.02084.x.

Notess, Laura, Peter Veit, Iliana Monterroso, Andiko, Emmanuel Sulle, Anne M. Larson, Anne-Sophie Gindroz, Julia Quaedvlieg, and Andrew Williams. 2018. The Scramble for Land Rights. Washington, D.C.: World Resources Institute. https://www.wri.org/publication/scramble-for-land-rights.

NYDF Assessment Partners. 2019. Protecting and Restoring Forests: A Story of Large Commitments yet Limited Progress. New York Declaration on Forests Five-Year Assessment Report. Climate Focus. https://forestdeclaration.org/images/uploads/resource/2019NYDFReport.pdf. 
Opdam, Paul, Joan Iverson Nassauer, Zhifang Wang, Christian Albert, Gary Bentrup, JeanChristophe Castella, Clive McAlpine, Jianguo Liu, Stephen Sheppard, and Simon Swaffield. 2013. "Science for Action at the Local Landscape Scale." Landscape Ecology 28 (8): 1439-1445. doi:10.1007/s10980-013-9925-6.

Ostrom, Elinor. 1990. Governing the Commons: The Evolution of Institutions for Collective Action. Cambridge, UK: Cambridge University Press. doi:10.1017/CBO9780511807763.

Perera, Ajith H., Urmas Peterson, Guillermo Martínez Pastur, and Louis R. Iverson. 2018. Ecosystem Services from Forest Landscapes: Broadscale Considerations. Cham, Switzerland: Springer.

Phillips, Adrian. 1998. "The Nature of Cultural Landscapes - a Nature Conservation Perspective." Landscape Research 23 (1): 21-38. doi:10.1080/01426399808706523.

Pierre, Jon, and B. Guy Peters. 2000. Governance, Politics, and the State. London: MacMillan.

Potapov, Peter, Matthew C. Hansen, Lars Laestadius, Svetlana Turubanova, Alexey Yaroshenko, Christoph Thies, Wynet Smith, et al. 2017. "The Last Frontiers of Wilderness: Tracking Loss of Intact Forest Landscapes from 2000 to 2013." Science Advances 3 (1). American Association for the Advancement of Science: e1600821. doi:10.1126/sciadv.1600821.

Puettmann, Klaus J., Scott McG Wilson, Susan C. Baker, Pablo J. Donoso, Lars Drössler, Girma Amente, Brian D. Harvey, et al. 2015. "Silvicultural Alternatives to Conventional Even-Aged Forest Management - What Limits Global Adoption?" Forest Ecosystems 2 (1): 8. doi:10.1186/s40663-015-0031-x.

Reed, James, Josh van Vianen, Jos Barlow, and Terry Sunderland. 2017. "Have Integrated Landscape Approaches Reconciled Societal and Environmental Issues in the Tropics?" Land Use Policy 63 (Supplement C): 481-492. doi:10.1016/j.landusepol.2017.02.021.

Reed, James, Josh Van Vianen, Elizabeth L. Deakin, Jos Barlow, and Terry Sunderland. 2016. "Integrated Landscape Approaches to Managing Social and Environmental Issues in the Tropics: Learning from the Past to Guide the Future." Global Change Biology 22 (7): 2540-2554. doi:10.1111/gcb.13284.

Rhodes, R. A. W. 1997. Understanding Governance: Policy Networks, Governance, Reflexivity and Accountability. Buckingham: Open University Press.

Samndong, Raymond Achu, Glenn Bush, Arild Vatn, and Melissa Chapman. 2018. "Institutional Analysis of Causes of Deforestation in REDD+ Pilot Sites in the Equateur Province: Implication for REDD+ in the Democratic Republic of Congo." Land Use Policy 76 (July): 664-674. doi:10.1016/j.landusepol.2018.02.048.

Sampford, Charles, Timothy Cadman, and Rowena Maguire, eds. 2017. Governing the Climate Change Regime: Institutional Integrity and Integrity Systems. New York: Routledge. doi:10.4324/9781315442365.

Sayer, Jeffrey A., Stewart Maginnis, and Michelle Laurie. 2005. Forests in Landscapes: Ecosystem Approaches to Sustainability. London; Sterling, VA: Earthscan.

Sayer, Jeffrey A., Chris Margules, Agni K. Boedhihartono, Terry Sunderland, James D. Langston, James Reed, Rebecca Riggs, et al. 2017. "Measuring the Effectiveness of Landscape Approaches to Conservation and Development." Sustainability Science 12 (3): 465-476. doi:10.1007/s11625-016-0415-z.

Sayer, Jeffrey A., Terry Sunderland, Jaboury Ghazoul, Jean-Laurent Pfund, Douglas Sheil, Erik Meijaard, Michelle Venter, et al. 2013. "Ten Principles for a Landscape Approach to Reconciling Agriculture, Conservation, and Other Competing Land 
Uses." Proceedings of the National Academy of Sciences 110 (21): 8349-8356. doi:10.1073/pnas.1210595110.

Schwartzman, Stephan, and Barbara Zimmerman. 2005. "Conservation Alliances with Indigenous Peoples of the Amazon." Conservation Biology 19 (3): 721-727. doi:10.1111/j.1523-1739.2005.00695.x.

Secretariat of the Convention on Biological Diversity. 2014. Connecting Biodiversity and Climate Change Mitigation and Adaptation: Report of the Second Ad Hoc Technical Expert Group on Biodiversity and Climate Change. Technical Series 41. Montreal, Canada. https://www.cbd.int/doc/publications/cbd-ts-41-en.pdf.

Seddon, Nathalie, Alexandre Chausson, Pam Berry, Cécile A. J. Girardin, Alison Smith, and Beth Turner. 2020. "Understanding the Value and Limits of Nature-Based Solutions to Climate Change and Other Global Challenges." Philosophical Transactions of the Royal Society B: Biological Sciences 375 (1794): 20190120. doi:10.1098/rstb.2019.0120.

Selman, Paul. 2004. "Community Participation in the Planning and Management of Cultural Landscapes." Journal of Environmental Planning and Management 47 (3): 365-392. doi:10.1080/0964056042000216519.

Selman, Paul. 2005. Planning and the Landscape Scale. London, UK: Taylor and Francis. Selman, Paul. 2009. "Planning for Landscape Multifunctionality." Sustainability: Science, Practice and Policy 5 (2): 45-52. doi:10.1080/15487733.2009.11908035.

Shackleton, Ross T., Per Angelstam, Benjamin van der Waal, and Marine Elbakidze. 2017. "Progress Made in Managing and Valuing Ecosystem Services: A Horizon Scan of Gaps in Research, Management and Governance." Ecosystem Services, January. doi:10.1016/j.ecoser.2016.11.020.

Shepherd, Gill. 2008. The Ecosystem Approach: Learning from Experience. Gland, Switzerland: IUCN.

Sitas, Nadia, Heidi E. Prozesky, Karen J. Esler, and Belinda Reyers. 2014. "Opportunities and Challenges for Mainstreaming Ecosystem Services in Development Planning: Perspectives from a Landscape Level.” Landscape Ecology 29 (8): 1315-1331. doi:10.1007/s10980-013-9952-3.

Smith, Dr Richard D., and Edward Maltby. 2003. Using the Ecosystem Approach to Implement the Convention on Biological Diversity: Key Issues and Case Studies. IUCN.

Spracklen, D. V., S. R. Arnold, and C. M. Taylor. 2012. "Observations of Increased Tropical Rainfall Preceded by Air Passage over Forests." Nature 489 (7415): 282-285. doi:10.1038/nature11390.

Tavares, A. O., Mário Monteiro, M. A. Vargas, R. L. Pato, and Rita Serra. 2014. "Land Use Change and Forest Routing in a Rural Context: The Relevance of the CommunityBased Management and Planning Framework." Applied Geography 52 (August): 153-171. doi:10.1016/j.apgeog.2014.05.008.

Tress, Bärbel, and Gunther Tress. 2001. "Capitalising on Multiplicity: A Transdisciplinary Systems Approach to Landscape Research." Landscape and Urban Planning, Bridging human and natural sciences in landscape research, 57 (3): 143-157. doi:10.1016/S0169-2046(01)00200-6.

Tyukavina, Alexandra, Matthew C. Hansen, Peter V. Potapov, Stephen V. Stehman, Kevin Smith-Rodriguez, Chima Okpa, and Ricardo Aguilar. 2017. "Types and Rates of Forest Disturbance in Brazilian Legal Amazon, 2000-2013." Science Advances 3 (4): e1601047. doi:10.1126/sciadv.1601047. 
UNFCCC. 2001. "Definitions, Modalities, Rules and Guidelines Relating to Land Use, LandUse Change Andforestry Activities under the Kyoto Protocol." United Nations. https:/unfccc.int/files/meetings/workshops/other_meetings/application/pdf/11cp7.pdf.

Valencia-Sandoval, Cecilia, David N. Flanders, and Robert A. Kozak. 2010. "Participatory Landscape Planning and Sustainable Community Development: Methodological Observations from a Case Study in Rural Mexico." Landscape and Urban Planning 94 (1): 63-70. doi:10.1016/j.landurbplan.2009.07.018.

Vincent, Jeffrey R. 2012. Ecosystem Services and Green Growth. Working Paper 6233. Policy Research Working Paper. Washington, D.C.: World Bank.

Watson, James E. M., Tom Evans, Oscar Venter, Brooke Williams, Ayesha Tulloch, Claire Stewart, Ian Thompson, et al. 2018. "The Exceptional Value of Intact Forest Ecosystems." Nature Ecology \& Evolution 2 (4): 599-610. doi:10.1038/s41559-0180490-x.

Watson, Vanessa. 2014. "Co-Production and Collaboration in Planning - The Difference." Planning Theory \& Practice 15 (1). Routledge: 62-76. doi:10.1080/14649357.2013.866266.

Watts, Matthew E., Romola R. Stewart, Tara G. Martin, Carissa J. Klein, Josie Carwardine, and Hugh P. Possingham. 2017. "Systematic Conservation Planning with Marxan." In Learning Landscape Ecology: A Practical Guide to Concepts and Techniques, edited by Sarah E. Gergel and Monica G. Turner, 211-227. New York, NY: Springer. doi:10.1007/978-1-4939-6374-4 13.

Waylen, K. A., E. J. Hastings, E. A. Banks, K. L. Holstead, R. J. Irvine, and K. L. Blackstock. 2014. "The Need to Disentangle Key Concepts from EcosystemApproach Jargon." Conservation Biology 28 (5): 1215-1224. doi:10.1111/cobi.12331.

Whittemore, Andrew H. 2015. "Practitioners Theorize, Too: Reaffirming Planning Theory in a Survey of Practitioners' Theories." Journal of Planning Education and Research 35 (1): 76-85. doi:10.1177/0739456X14563144.

Zimmerman, Barbara, Carlos A. Peres, J. R. Malcolm, and Terence Turner. 2001. "Conservation and Development Alliances with the Kayapó of South-Eastern Amazonia, a Tropical Forest Indigenous People.” Environmental Conservation 28 (01). doi:10.1017/S0376892901000029.

Zimmerman, Barbara, Stephen Schwartzman, Adriano Jerozolimski, Junio Esllei, Edson Santini, and Sonia Hugh. 2020. "Large Scale Forest Conservation With an Indigenous People in the Highly Threatened Southeastern Amazon of Brazil: The Kayapo." In Reference Module in Earth Systems and Environmental Sciences, B9780124095489118000. Elsevier. doi:10.1016/B978-0-12-409548-9.11918-9. 